\title{
Simulation of the \\ Long-Term Accumulation of Radiocontaminants in Crop Plants
}

R. G. Schreckhise

March 1980

Prepared for the U.S. Department of Energy under Contract EY-76-C-06-1830

Pacific Northwest Laboratory Operated for the U.S. Department of Energy by Battelle Memorial Institute 


\title{
NOTICE
}

This report was prepated as an account of work sponsored by the United States Government. Neither the United States nor the Department of Energy, nor any of their employees, nor any of their contractors, subcontractors, or their employees, makes any warranty. express or implied, or assumes any legal liability or responsibility for the accuracy, completeness or usefulness of any information, apparatus, product or process disclosed, or represents that its use would not infringe privately owned rights.

The views, opinions and conclusions contained in this repont are those of the contractor and do nor necessarily represent those of the United States Government or the United States Department of Energy.

\author{
PACIFIC NORTHWEST LABORATORY \\ operated by \\ BATTELLE \\ for the \\ UNITED STATES DEPARTMENT OF ENERCY \\ Under Contract EY-76-C-06-1830
}
Printed in the United States of America Avaliable from
Nationat Technical Inlormalion Service
United States Degartment of Cominerce
$\$ 205$ Poit Royal Road
Springlieid, Virginia 22151

Price: Printed Copys

\&: Microfiche $\$ 3.00$

\begin{tabular}{|c|c|}
\hline Pages & $\begin{array}{l}\text { NTIS } \\
\text { Selling Price }\end{array}$ \\
\hline $001-025$ & $\$ 4 . \infty$ \\
\hline $026-050$ & 450 \\
\hline $051-075$ & 55.25 \\
\hline $075-100$ & 56.00 \\
\hline $101-125$ & $\$ 6.50$ \\
\hline $126-150$ & 57.25 \\
\hline $151-175$ & $\$ 8.00$ \\
\hline $176-200$ & 59.00 \\
\hline $201-225$ & 59.25 \\
\hline $226-250$ & 5950 \\
\hline $251-275$ & $\$ 10.75$ \\
\hline $276-300$ & $\$ 11.00$ \\
\hline
\end{tabular}


SIMULATION OF THE LONG-TERM

IN CROP PLANTS

R. G. Schreckhise

March 1980

Prepared for the

U.S. Department of Energy

under Contract EY-76-C-06-1930

Pacific Northwest Laboratory

Richland, Washington 99352 
更

.

$\checkmark$ 


\section{EXECUTIVE SUMMARY}

The long-term input of radiocontaminants into agricultural ecosystems can be of concern if the resulting accumulation of radionuclides in the edible vegetation contributes to the radiation exposure of the general population. The radiocontaminants could enter the system either by atmospheric deposition or through the use of contaminated irrigation water. The possible sources of contaminants could be global fallout, operating nuclear facilities, or the discharge waters from naturally occurring uranium ore bodies or geologic nuclear waste repositories.

In the past, a model was used to estimate exposures in situations where radiocontaminants were chronically released into the irrigation water over long periods of time. For this model, termed the Fifty-Year Accumulation Method (FYAM), it was assumed that the quantities of radionuclides that would accumulate in the agricultural soils at any given time would be equal to the total quantity deposited within a 50-year period. However, since some of the radionuclides could be discharged into the biosphere over millions of years, questions arose concerning the accumulation patterns of radiocontaminants in the soil over much longer periods of time. Another model, named CROPRE, was developed to predict both the long-term accumulation of radionuclides and the resulting concentrations of radionuclides in vegetation. This model was designed to include: 1) the chronic input of contaminated irrigation water into both the soil compartment and directly onto the surface of the vegetation; 2) the incorporation of radiocontaminants in the soil organic matter pool and their eventual release for re-uptake by subsequent crops; 3 ) the removal of contaminants from the system when the crops are harvested; and 4) the downward movement of radionuclides and their loss from the system by percolation.

Both the FYAM and the CROPRE models were used to estimate radionuclide concentrations in edible vegetation over various periods of time. There were significant discrepancies between the estimates of the two models. When the system was not overwatered and percolation did not occur, estimates of radionuclide concentration in edible vegetation from the CROPRE model generally exceeded the FYAM values after 88 years of irrigation with contaminated water. 
The maximum estimates from the CROPRE model, which usually occurred at times greater than 1000 years, ranged up to a factor of 120 larger than the values from the FYAM model. The maximum CROPRE estimates for radionuclides that are discriminated against by plants exceeded the corresponding FYAM values by greater margins than for those elements with larger plant uptake rates. The degree to which an element is sorbed onto soil had the greatest effect on the predicted concentrations of radionuclides in edible plant material when the system was overwatered. The FYAM values exceeded the maximum estimates from CROPRE for radionuclides that are slightly retarded from percolating through the soil and are readily taken up by plants. Conversely, estimates from CROPRE exceeded the corresponding FYAM values for radionuclides that are retarded by soil and have relatively small plant uptake values.

The CROPRE model more realistically simulates the cycling of radiocontaminants in crop plants over long periods of time than does the FYAM model. Therefore, the predicted values obtained using CROPRE should be more accurate than the corresponding FYAM estimates. The CROPRE model may need several modifications to increase its usefulness and precision as a predictive tool; however, with or without these modifications, it is recommended that it be incorporated into existing radiation dose commitment models. 


\section{ACKNOWLEDGMENTS}

This study was supported in part by the Assessment of Effectiveness of Geologic Isolation Systems (AEGIS) program, formerly the Waste Isolation Safety Assessment Program (WISAP) and in part by the Radioecology of Nuclear Fuel Cycles (RNFC) project, both conducted at Pacific Northwest Laboratory (PNL). The AEGIS/WISAP program was supported by the Office of Waste Isolation (OWI), managed for the U.S. Department of Energy (DOE) by Union Carbide Nuclear Corporation. In July 1978 OWI was replaced by the Office of Nuclear Waste Isolation (ONWI), managed for DOE by the Project Management Division of Battelle Memorial Institute. The RNFC project was supported by the Office of Health and Environmental Research, DOE Headquarters, Germantown.

Appreciation is expressed to R. C. Routson (Rockwell Hanford Operations), J. K. Soldat (PNL), and H. C. Burkholder (ONWI) for their suggestions and comments during this study; to the typist, Karen Tallent; and to the editor, Linda King, for her persistance and perserverance. Appreciation is also expressed to A. Brandstetter, D. A. Cataldo, T. R. Garland, J. K. Soldat, D. A. Baker, J. M. Thomas, and R. E. Wildung for their helpful review of this document. 

CONTENTS

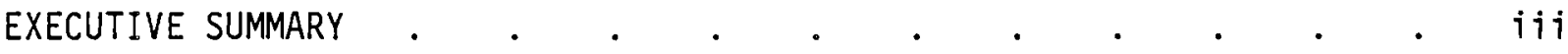

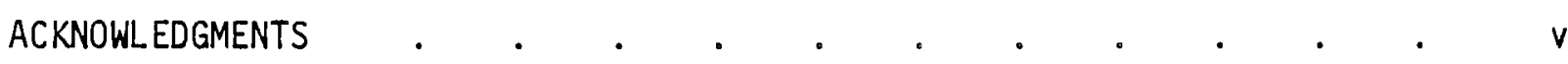

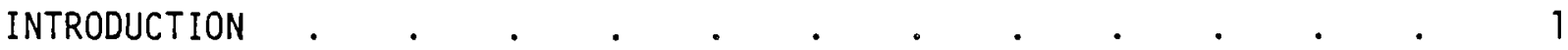

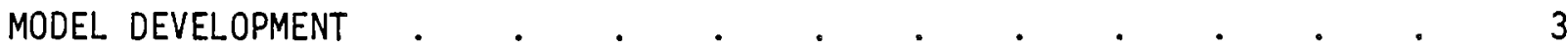

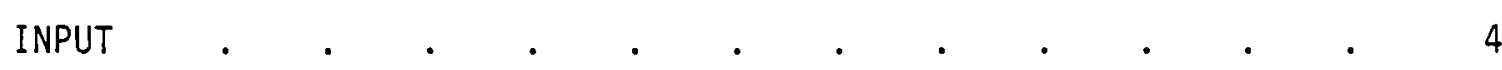

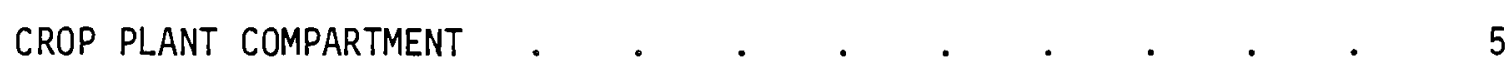

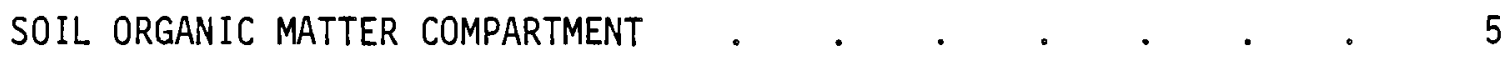

SOIL MINERAL COMPARTMENT • . . . . . . . . . . . . 8

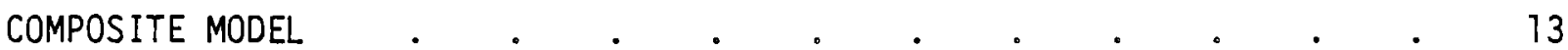

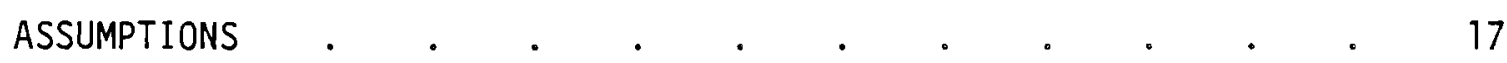

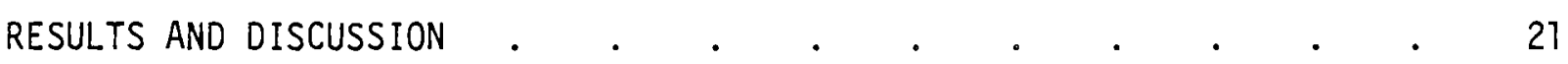

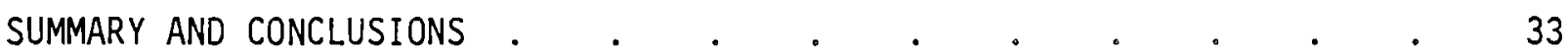

RECOMMENDED MODIFICATIONS OF CROPRE

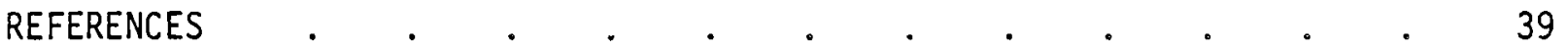

APPENDIX A 
FIGURES

1 Generalized Compartmental Transfer of Radionuclides Through Soil/Plant Systems . $. \quad . \quad . \quad . \quad . \quad . \quad . \quad . \quad$.

2 Compartmental Transfer of Carbon Through Subcompartments of the Soil Organic Matter Pool . . . . . . . . . . . .

3 Compartmental Model Describing the Long-Term Accumulation of Radionuclides in Crop Plants . . . . . . . . . . . .

4 Long-Term Accumulation of $99 \mathrm{Tc}$ in Various Compartments of a Crop Plant System . . . . . . . . . . . .

5 The Effect of Varying Irrigation Regimes and Concentration Ratios on the Accumulation of ${ }^{99} \mathrm{Tc}$ in Seeds as a Function of Time. .

6 The Effect of Changing the Concentration Ratio Value on the Accumulation of ${ }^{239} \mathrm{Pu}$ in Seeds When the System is not Overwatered . .

\section{TABLES}

1 Compartments of the Soil Organic Matter Pool and Their Associated Half-Times as Reported by Jenkinson and Rayner . . . . .

2. Transfer Coefficients, $k_{i j}$, Describing the Fractional Transfer of Materials to Compartment $i$ from $j$ per Year . . . . .

3 Comparison of the Concentrations of Radionuclides in Seeds Predicted by the Fifty-Year Accumulation Method and by the Long-Term Accumulation Method 


\section{SIMULATION OF THE LONG-TERM ACCUMULATION \\ OF RADIOCONTAMINANTS IN CROP PLANTS}

R. G. Schreckhise

\section{INTRODUCTION}

Most radiological dose assessment models ignore the long-term buildup of radiocontaminants in the soil. When they estimate levels in crop plants from root uptake, these models account only for the annual input from the source into the soil. Almost all of the models ignore the build-up of contaminants in the soil profile due to the accumulation in the roots and the build-up from the above-ground plant material that is buried by plowing. The model described in this report simulates the entire system involved in the cycling and accumulation of radionuclides in cultivated land.

An assessment of this mode of radiation exposure to populations was made by Burkholder et a1. (1975). They considered radiation doses from ingesting contaminated vegetation, as well as doses from immersion in water, consuming fish, and other exposure routes. Their approach was to estimate the concentration of radionuclides in soil after 50 years of irrigation with contaminated water. Their estimate was corrected for physical decay. The amount in the soil was then kept constant and levels of radionuclides in the vegetation were estimated by using concentration ratio (CR) values, which relate vegetation to soil concentrations. Levels in the vegetation were also adjusted to include radionuclides deposited externally on the plant and transferred to the edible parts. An accumulated 50-year dose was then estimated; the vegetation content was assumed to remain constant. One of the major concerns arising from this approach was whether the 50-year accumulation was a sufficiently realistic way to account for the long-term build-up of radionuclides in soil.

One important aspect not considered by Burkholder et a 1. (1975) is the accumulation of the radiocontaminants in the soil that are released from decaying contaminated vegetative material (such as roots, leaves, stems, etc. which, 
depending on the crop, may not be harvested). As this material is decomposed, the released radionuclides are available to be taken up by the roots of the new crop and transported to the aerial parts. Burkholder et al. (1975) also neglected to consider the loss of radionuclides from the system through percolation and harvest. The model described here addresses these questions. 


\section{MODEL DEVELOPMENT}

The basic routes of exchange and other processes involved in the accumulation of radionuclides by plants are illustrated in Figure 1 . The dashed lines indicate routes that exist but were not included in this initial model formulation. The input to the system is assumed to be from sprinkler irrigation with water contaminated with radionuclides. Contaminated water is applied directly to the plant exterior, as well as to the soil surface. The radionuclides on the surface of the vegetation are transferred in part to the edible plant parts, in part to the soil by weathering, and part remains on the vegetative surfaces. The radionuclides deposited on the soil surface are mixed in the upper 15 to $30 \mathrm{~cm}$ of soil by plowing. They also move downward through the soil profile by percolation. The radionuclides in the soil profile are taken up by the roots and transferred to the edible parts of the plant, which are harvested and consumed by man. Other portions of the radionuclides, taken up initially by the soil minerals and the organic matter, are available for plant uptake following chemical and biological degradation. The remaining radionuclides are lost from the root-zone by leaching if the crop plants are

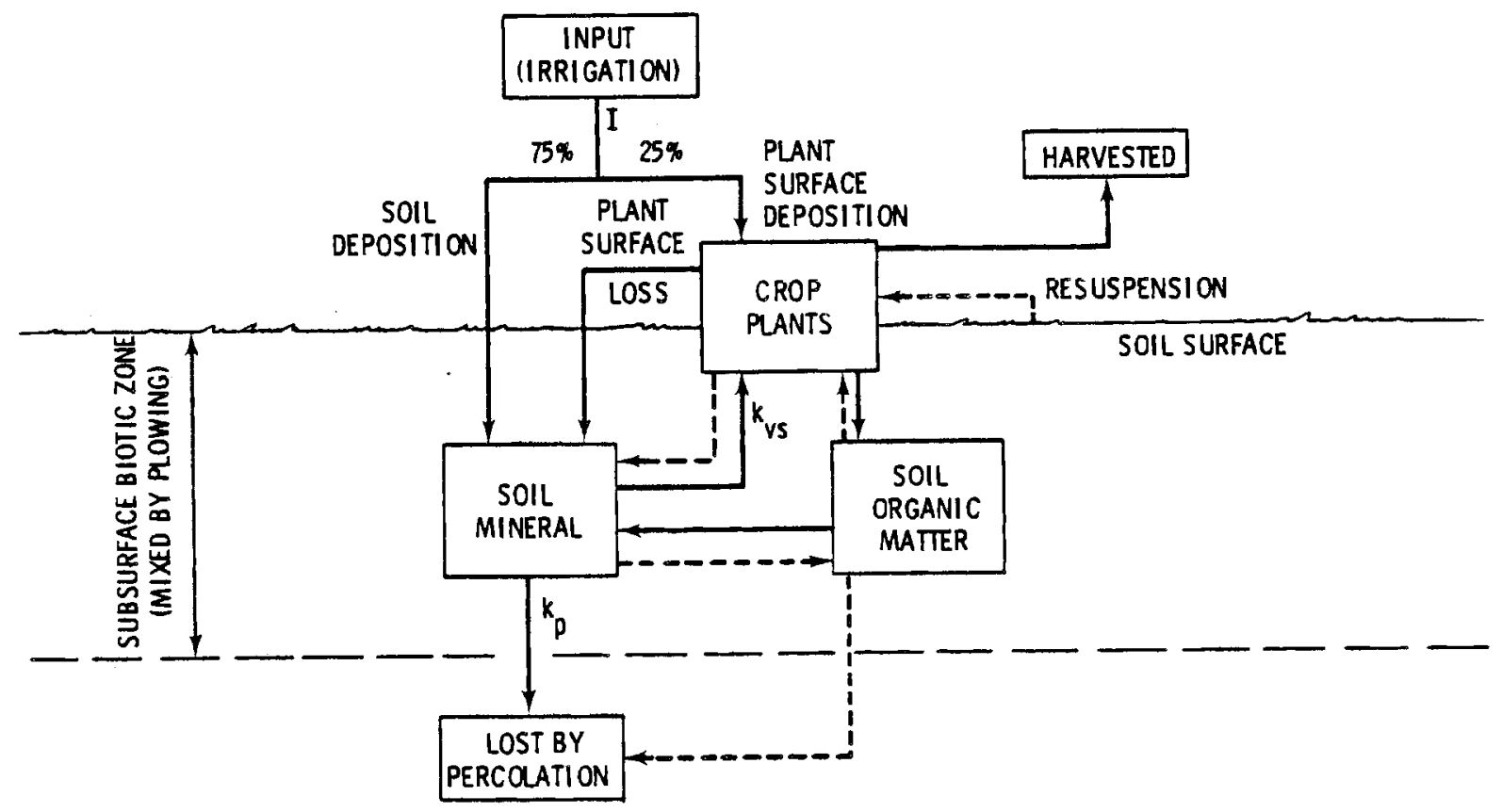

FIGURE 1. Generalized Compartmental Transfer of Radionuclides through Soil/Plant Systems 
overwatered. The transfer of radionuclides through most of these pathways has been used frequentiy to construct various dose-assessment models in the past (Soldat 1971, and Booth, Kay, and Rohwer 1971).

INPUT

Irrigation water is sprinkled onto the crops at an assumed rate of $150 \mathrm{l} / \mathrm{m}^{2}$ per month during the 90 -day growing season. This value, as well as many of the other parameters, was taken from ERDA (1975) and Soldat (1971) for comparison with the results from the dose-assessment models used in those studies. The $150 \mathrm{l} / \mathrm{m}^{2}$.month value was assumed to be equal to the total amount of water transpired by the plants, evaporated form the soil, and retained by the plants and the soil. If the crops are irrigated at a rate exceeding $150 \mathrm{l} / \mathrm{m}^{2} \cdot$ month, the excess percolates downward through the soil and becomes unavailable to the plant roots. Overwatering is a common practice to prevent salt build-up in areas where the irrigation water has a high mineral content. Precipitation, both during and after the growing season, was assumed to be small enough so that the percolation downward from the root-zone was caused only by overwatering.

If $f_{w}$ is the fractional overwatering rate (fraction of the irrigation water that is lost to the system via percolation), then the yearly irrigation rate is:

$$
\left(150 \mathrm{l} / \mathrm{m}^{2} \cdot \text { month }\right)(3 \text { month } / 0.25 \mathrm{yr})=\left(1+f_{W}\right) 1800 \mathrm{l} / \mathrm{m}^{2} \cdot \mathrm{yr}
$$

For simplicity, the concentration of radionuclides in the water was set at 1.0 units of activity per liter $(1.0 \mathrm{VOA} / \mathrm{l})$. During the 90 -day growing season, radionuclides are added to the plant and soil surfaces at a rate (I) of:

$$
\begin{aligned}
& I=\left(1+f_{W}\right)\left(1800 \ell / \mathrm{m}^{2} \cdot y r\right)(1.0 \mathrm{UOA} / \mathrm{l}) \\
& I=\left(1+f_{W}\right)\left(1800 \mathrm{UOA} / \mathrm{m}^{2} \cdot \mathrm{yr}\right)
\end{aligned}
$$


Of this amount, $25 \%$ is assumed to be retained by the crop surface and the remaining $75 \%$ is deposited directly onto the soil surface. The material on the plant surface that is weathered with an environmental half-time of 14 days is assumed to be deposited onto the soil surface.

\section{CROP PLANT COMPARTMENT}

The "crop plant" is a grain, such as barley or wheat, with an above-ground yield of $1.4 \mathrm{~kg}$ wet weight per $\mathrm{m}^{2}$ (ERDA 1975). The below-ground biomass is assumed to be the same. Forty percent of the above-ground biomass, or $20 \%$ of the entire plant, is assumed to be harvested annualiy. The remaining $80 \%$ is plowed back into the soil, becoming part of the soil organic matter pool.

Radionuclides enter the Crop Plant Compartment by two routes: 1) root uptake and 2) surface contamination from sprinkler irrigation. During the 90-day growing season, material is allowed to accumulate from the two routes; after this period, the grain is harvested and removed from the system. Levels of radionuclides in the edible portions are estimated by assuming that the seeds will have the same concentration as the plant tissue (both shoots and roots) that accumulated the radionuclide material, by root uptake only, during the growing season. The translocation ratio that describes the ratio of the radionuclide concentration in the grain to the concentration in the plant (resulting from surface contaminations only) was set equal to 0.1 at the time of harvest.

\section{SOIL ORGANIC MATTER COMPARTMENT}

The Soil Organic Matter Compartment consists of the unharvested plant materials, including roots and above-ground parts, that are plowed back into the upper 15 to $30 \mathrm{~cm}$ of soil each year. This organic matter is slowiy broken down by decomposers, such as insects, earthworms, fungi, and bacteria. Decomposition is an important ecological process that is necessary for mineral recycling. A subsequent step--the transfer of material back into the Soil Mineral Compartment after it is released by decomposition of the soil organic matter--is a potentially important route for the transfer of radionuclides. This transfer process, shown in Figure 1 , usually is not considered in other models. 
One major difficulty in developing mineral cycling models is the lack of information on the decomposition rates of organic matter. These rates were investigated by Jenkinson and Rayner (1977) using data from the long-term field experiments conducted at the Rothamsted Experimental Station near Harpenden, Harts, England. In these experiments, field plots have been maintained for over 100 years with consistent agricultural practices. These experiments provide a unique data base for use in constructing a mineral cycling model that collates the results of years of observations on the cycling of soil organic matter. Their model, which concerned the Rothamsted soils and environments only, is assumed to have applications to other soils and environments.

The Jenkinson and Rayner (1977) model, developed to simulate the amount of carbon in the soil organic matter, was modified in this study by combining certain parameters to facilitate use of a time-dependent deterministic model. The modified model is illustrated in Figure 2 . The five compartments

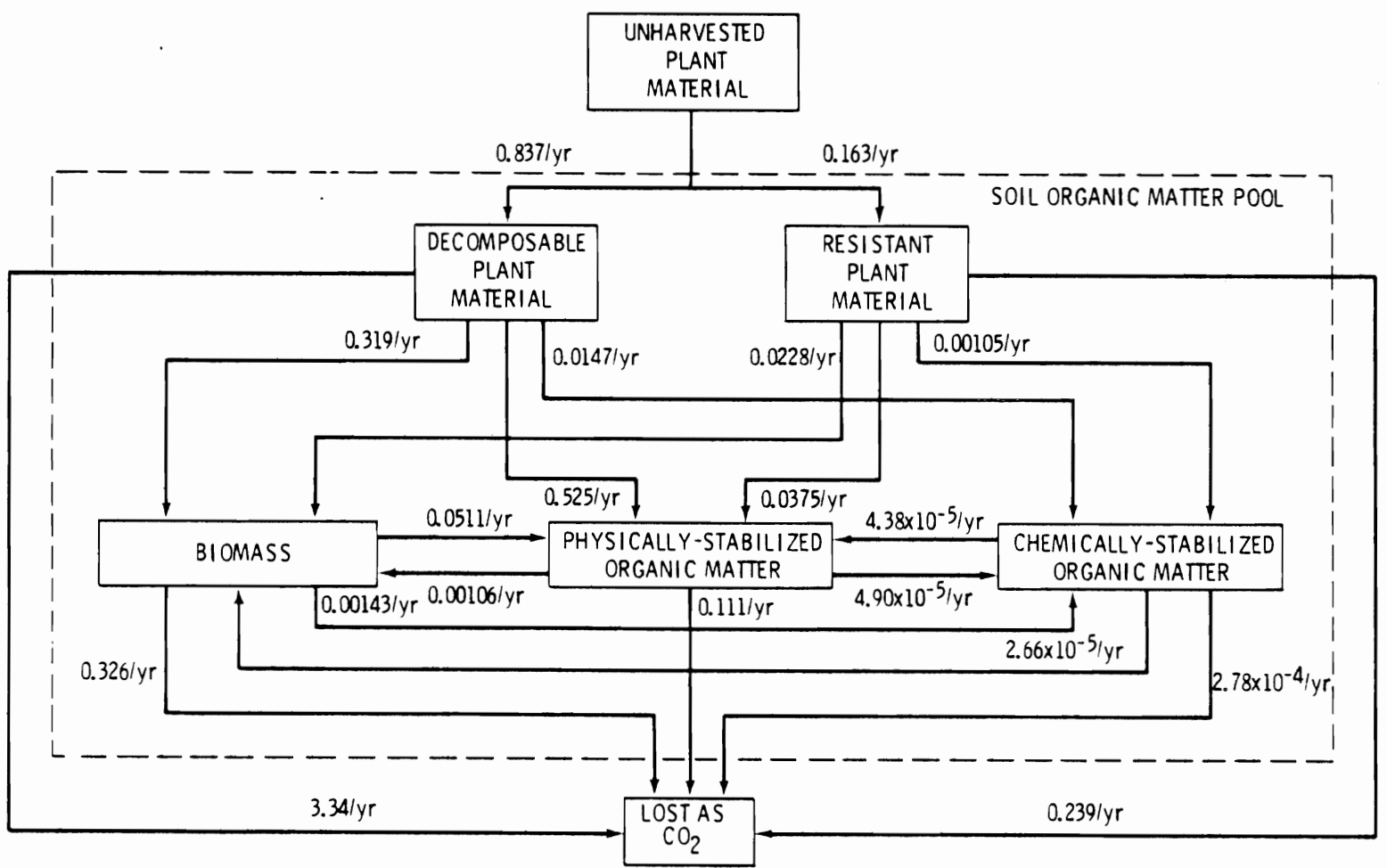

FIGURE 2. Compartmental Transfer of Carbon Through Subcompartments of the Soil Organic Matter Pool (modified from Jenkinson and Rayner 1977) 
representing the soil organic matter pool are described in Table 1. Carbon released by decomposition of organic matter from the Decomposable Plant Material (DPM) or Resistant Plant Material (RPM) Compartments is either transferred to the Biomass (BIO), Physically-stabilized Organic Matter (POM), and Chemically-stabilized Organic Matter (COM) Compartments or it is released from the soil organic matter pool as $\mathrm{CO}_{2}$. The carbon in each of the last three compartments can be lost from the system as $\mathrm{CO}_{2}$ or it can be transferred to one of the other two compartments. The Jenkinson and Rayner model was used to obtain the compartment masses that are listed in Table 1. The values were estimated by starting with a zero amount of soil organic matter and adding $2.24 \mathrm{~kg}$ of wet vegetation $/ \mathrm{m}^{2}$ each year. The model was evaluated for a total of 20,000 years; at which time the soil organic matter content in each compartment had reached a steady state.

TABLE 1. Compartments of the Soil Organic Matter Pool and Their Associated Half-Times as Reported by Jenkinson and Rayner (1977). The Compartment Mass Values Were Estimated Using a Modification of the Jenkinson and Rayner Model.

\begin{tabular}{|c|c|c|c|}
\hline Compartment & Description & $\begin{array}{c}\text { Ha lf-Time, } \\
y r\end{array}$ & $\begin{array}{c}\text { Mass, } \mathrm{kg} \\
\text { wet } / \mathrm{m}^{2} \\
\end{array}$ \\
\hline DPM & $\begin{array}{l}\text { Decomposable plant material--makes } \\
\text { up } 83.7 \% \text { of the plant material that } \\
\text { is put into the soil organic matter } \\
\text { pool each year }\end{array}$ & 0.16 & 0.0170 \\
\hline RPM & $\begin{array}{l}\text { Resistant plant material--resistant } \\
\text { plant material that comprises } 16.3 \% \\
\text { of the total input each year }\end{array}$ & 2.3 & 1.03 \\
\hline BIO & $\begin{array}{l}\text { Biomass--the biological organisms } \\
\text { that are responsible for the decom- } \\
\text { position of the plant material }\end{array}$ & 1.7 & 0.480 \\
\hline POM & Physically-stabilized organic matter & 50 & 25.2 \\
\hline COM & Chemically-stabilized organic matter & 2000 & 28.2 \\
\hline
\end{tabular}

The material in each compartment was treated as a single portion being decomposed by biological degradation, as described by a first-order rate process in both Figure 1 and Figure 2. The processes were assumed to be independent of each other. The first-order rate constants 1 isted in Figure 2 
show the fraction of carbon in a particular compartment that is transferred to another compartment during each year. The rate constants were approximated by multiplying the half-times, listed in Table 1, by the fractional amount in each compartment that is transferred to a succeeding compartment yearly, as reported by Jenkinson and Rayner (1977).

To facilitate utilization of the Jenkinson and Rayner model to simulate the behavior of various radionuclides, one assumption is necessary: all of the elements and compounds act like carbon. This assumption is certainly not correct. However, since the breakdown and release rate of carbon will probably coincide, regulate, or at least affect their behavior, it may give a first approximation of the behavior of several radionuclides during the decomposition of soil organic matter.

\section{SOIL MINERAL COMPARTMENT}

The Soil Mineral Compartment in Figure 1 actually consists of several subcompartments. These physical and chemical subcompartments regulate the availability of compounds to be taken up by plant roots, transferred to the soil organic matter pool, or moved downward by water percolation. Development of a precise soil mineral model to simulate each of these processes was not included in this study.

The transfer of radionuclides from the Soil Mineral Compartment to plants by root uptake was approximated by modifying the values reported for the ratio of concentration of a radionuclide in vegetation to the concentration in the soil in which the plant was grown. Concentration ratio (CR) values are normally determined by growing vegetation in soil that has been amended with a known amount of the particular radionuclide. Care is usually taken to reduce or eliminate the resuspension of particles from other exterior sources on the plant surface. The plants are harvested at the desired maturity stage, and selected vegetative parts are analyzed for a particular radionuclide. To convert $C R$ values to transfer coefficients, i.e. fractional uptake per unit time, the following assumptions were made: 
- The annual yield of the crop is $2.8 \mathrm{~kg}$ of wet weight per square meter, divided equally between above- and below-ground plant parts.

- The growing season is 90 days long.

- The root-zone extends to a depth of $15 \mathrm{~cm}$ and the soil "surface" density is $224 \mathrm{~kg}$ dry soil// $\mathrm{m}^{2}$.

- The fractional uptake rate of the radionuclide from the Soil Mineral Compartment remains constant throughout the 90-day plant growth period; it is neither a function of the plant's size nor is it affected by physiological changes that occur in the plant during various growth stages.

- The radionuclide concentration of the above-ground plant parts is the same as that of the below-ground parts.

- The uptake of the material by the plant is not great enough to deplete the material from the soil during the growing season.

The transfer coefficient, describing the fractional uptake of the radionuclide from the soil mineral compartment by the plants per unit time, can be approximated from published CR values, such as those in $\mathrm{Ng}$ et a . (1968) and Baker, Heones, and Soldat (1976). The CR values are determined by dividing the observed concentration of a radionuclide in the vegetation by the concentrations of the radionuclide in the soil in which the plants were grown:

$$
C R=\frac{X \cup O A \text { per unit wet vegetation at maturity }}{Y \cup O A \text { per unit of dry soil at the beginning of plant growth }}
$$

The radionuclide concentration in vegetation can then be predicted for a given soil concentration with the following:

$$
X U O A / \mathrm{kg} \text { wet vegetation }=C R(Y \text { UOA } / \mathrm{kg} \text { dry soil) }
$$

The total UOA per square meter in the vegetation (V) and soil (S) is

$$
V U O A / m^{2}=(X U O A / \mathrm{kg} \text { wet vegetation })\left(2.8 \mathrm{~kg} \text { wet vegetation } / \mathrm{m}^{2}\right)
$$




$$
\text { S UOA } / \mathrm{m}^{2}=(Y \cup 0 A / \mathrm{kg} \text { dry soi })\left(224 \mathrm{~kg} \text { dry soi } 1 / \mathrm{m}^{2}\right)
$$

The fractional transfer from soil to vegetation per square meter during the 90-day growing season would be equal to Equation (4) divided by Equation $(5)$ or $V / S$. Then, the transfer coefficient $\left(k_{V S}\right)$, as a function of time, is

$$
k_{v S}=\frac{v}{s(0.25 y r)}
$$

When Equations (4) and (5) are substituted into (6),

$$
k_{V S}=\frac{(X \text { UOA } / \mathrm{kg} \text { vegetation })\left(2.8 \mathrm{~kg} \text { wet vegetation } / \mathrm{m}^{2}\right)}{(Y \text { UOA } / \mathrm{kg} \text { dry soi })\left(224 \mathrm{~kg} \mathrm{dry} \text { so } i 1 / \mathrm{m}^{2}\right)(0.25 \mathrm{yr})}
$$

Further substitution and reduction yields

$$
\begin{aligned}
& k_{v S}=(C R) \frac{\left(2.8 \mathrm{~kg} \text { wet vegetation } / \mathrm{m}^{2}\right)}{\left(244 \mathrm{~kg} \text { dry soi } 1 / \mathrm{m}^{2}\right)(0.25 \mathrm{yr})} \\
& k_{V S}=0.05 \mathrm{CR} \mathrm{yr}^{-1}
\end{aligned}
$$

If the $C R$ value is known, the transfer coefficient can be approximated by using Equation (7) for a given plant, soil type, and material.

The movement of radionuclides downward through the soil profile was approximated by using the sorption equilibrium constants $\left(\mathrm{K}^{-1}\right)$ listed in Burkholder et al. (1975) for western United States arid soil. The sorption equilibrium constants relate the movement of a nuclide $\left(V_{n}\right)$ to the flow rate of water $\left(V_{w}\right)$ as

$$
K^{-1}=\frac{V_{n}}{V_{w}}=\frac{1}{1+\frac{K_{d} \rho_{b}}{\theta}}
$$


where $K_{d}=$ distribution coefficient for the ionic species in the soil $(\mathrm{ml} / \mathrm{g})$, $\rho_{b}=$ bulk density of the soil $\left(\mathrm{g} / \mathrm{cm}^{3}\right)$, and $\theta=$ porosity $\left(\mathrm{m} 1 / \mathrm{cm}^{3}\right)$.

The transfer coefficient $\left(k_{p}\right)$ that describes the downward movement of a particular radionuclide past the root-zone where it becomes unavailable for plant uptake was estimated by first assuming that the water-holding capacity of the soil was $20 \%$. The amount of water in the soil at field-holding capacity would be

$$
(0.2)\left(224 \mathrm{~kg} / \mathrm{m}^{2}\right)=44.8 \mathrm{l} / \mathrm{m}^{2}
$$

From Equation ( 1 ), if $f_{w}$ is the fractional rate at which the crops are overwatered, then the amount of water that is lost by percolation is

$$
f_{W}=\left(1800 \ell / m^{2} \cdot y r\right)
$$

The fractional rate $\left(f_{p}\right)$ at which water in the top $15 \mathrm{~cm}$ of soil is washed out by percolation is

$$
f_{p}=\frac{f_{w}\left(1800 \mathrm{l} / \mathrm{m}^{2} \cdot y r\right)}{44.8 \mathrm{l} / \mathrm{m}^{2}}=0.402 f_{w} \mathrm{yr}^{-1}
$$

The transfer coefficient $\left(k_{p}\right)$ describing the downward migration of radionuclides by water movement is approximated by multiplying $f_{p}$ by Equation (8):

$$
k_{p}=f_{p} K^{-1}=0.402 k^{-1} f_{w} y r^{-1}
$$

Radionuclides enter the Soil Mineral Compartment through 1) decomposition of contaminated soil organic matter, 2) the plant roots (not included in this model since the $C R$ values allow for this), 3) direct irrigation onto the soil 
surface, and 4) material that is lost from the exterior of above-ground plant parts by various weathering mechanisms. The material deposited on the soil surface during the growing season is assumed to be mixed evenly throughout the top $15 \mathrm{~cm}$. The radionuclides in the Soil Mineral Compartment are assumed to be either available for uptake by plant roots or moved downward, away from the root-zone, by water percolation. 
The composite of all of the previousiy described compartments, subcompartments, and associated processes is illustrated in Figure 3 . The model was divided into ten compartments; each is connected by various processes depicted as arrows in Figure 3 . The dashed arrows indicate routes that may exist but were not included in this model. They can be added to the model in the future as information about them becomes available.

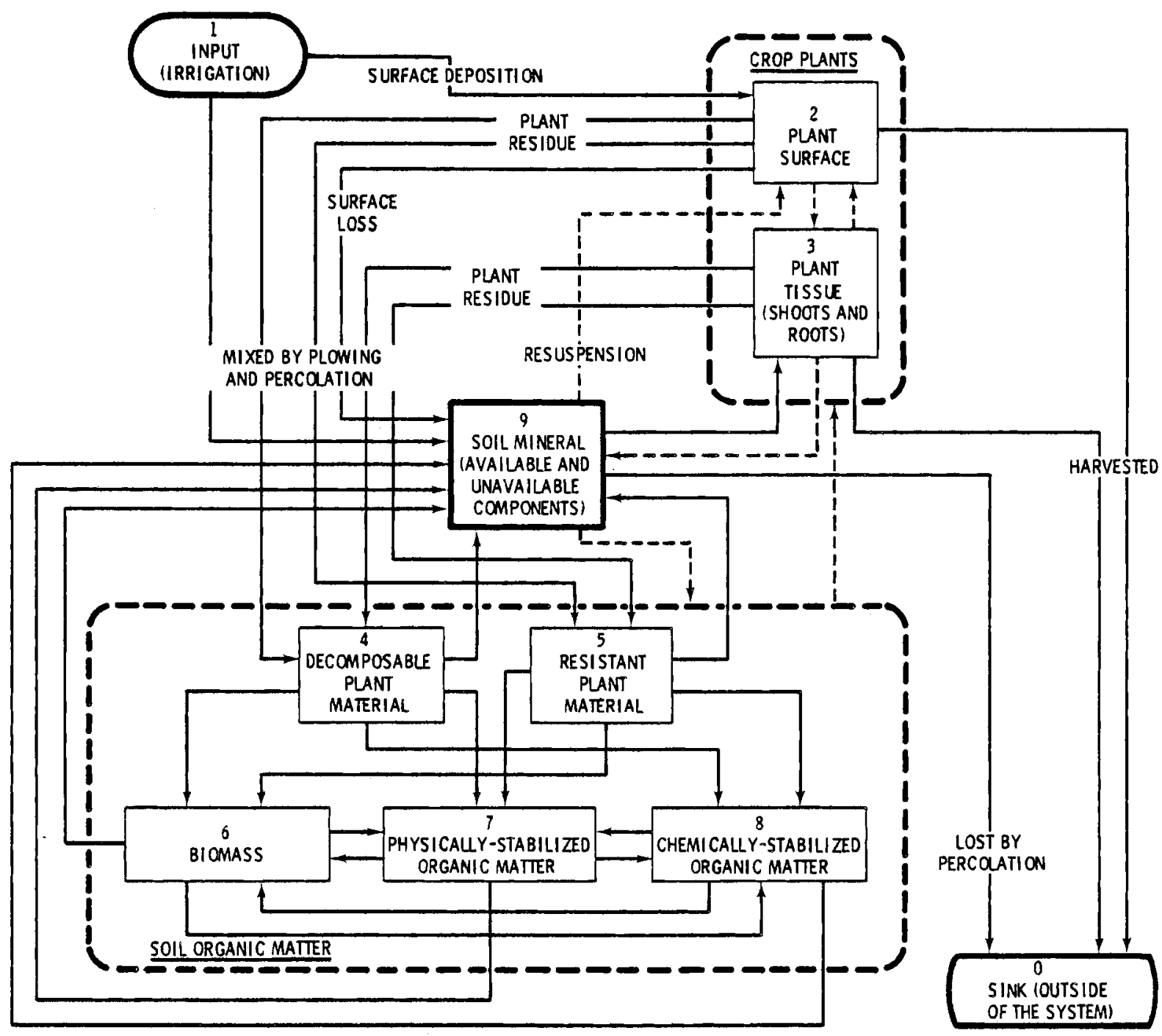

FIGURE 3. Compartmental Model Describing the Long-Term Accumulation of Radionuclides in Crop Plants 
The model was evaluated in yearly cycles. The input began at the start of each year and continued for 90 days. Plants began their growth at the beginning of each year and accumulated radionuclides through direct input from the irrigation water and through root uptake. At the end of the 90-day growing season, the edible plant parts were harvested and removed from the system. The remaining plant parts were added to the Soil Organic Matter Compartment. If the plants were overwatered, material in the Soil Mineral Compartment was lost from the system to the Sink Compartment by percolation. Irrigation, percolation, and plant growth ceased at the end of 90 days and did not begin again until the start of the next year; however, plant decomposition continued through the nongrowing as well as the growing season. The seed concentration values were determined at the end of each growing season.

The transfer coefficients $\left(k_{i j}\right)$ that describe the fractional transfer of radionuclides to Compartment $i$ from Compartment $j$ per unit time are listed in Table 2. For nonexisting pathways $\left(\mathrm{e} . \mathrm{g} ., k_{36}\right)$, zero values are listed. The quantity of material ( $Q$ ) in each compartment is expressed as units of activity per square meter $\left(U O A / \mathrm{m}^{2}\right)$. The tota 1 UOA in each square meter can be divided by the mass of the compartment per square meter (from Table 1) to approximate the concentration value $(U O A / \mathrm{kg})$. The values of the transfer coefficients change at various times: the inputs from irrigation, $k_{21}$ and $k_{90}$, are equal to zero except during the growing season ( $t=1$ to 90 days); the value for the quantity of material in Compartment $1\left(Q_{1}\right)$ is constant except for when it is decreased according to the physical decay constant $(\lambda)$ for that particular radioisotope $\left(\mathrm{k}_{01}\right)$; and the total quantity of radionuclides going onto the plant surface (Compartment 2) per unit time is $k_{21} Q_{1}$ and onto the soil surface (soil minera 1 pool, Compartment 9 ) is $k_{91} Q_{1}$. Likewise, root uptake $\left(k_{39}\right)$, weathering of material from the plant surface $\left(k_{92}\right)$, and percolation away from the root-zone $\left(k_{0 g}\right)$ occur only during the growing season and are equal to zero at all other times during the year. The crop is harvested at the end of the growing season ( $t=90$ days) when the values of $k_{42}, k_{43}, k_{52}, k_{53}, k_{02}$, and $k_{03}$ are changed to approximate the addition of material from the plants to the soil organic matter pools (Compartments 4 and 5) and the transfer of harvested material to the Sink. Transfers of material among the other compartments are assumed to remain constant throughout the year and not to be affected by any other processes. 
TABLE 2. Transfer Coefficients, $k_{i j}$, Describing the Fractional

Transfer of Material to Compartment $i$ from $j$ per Year

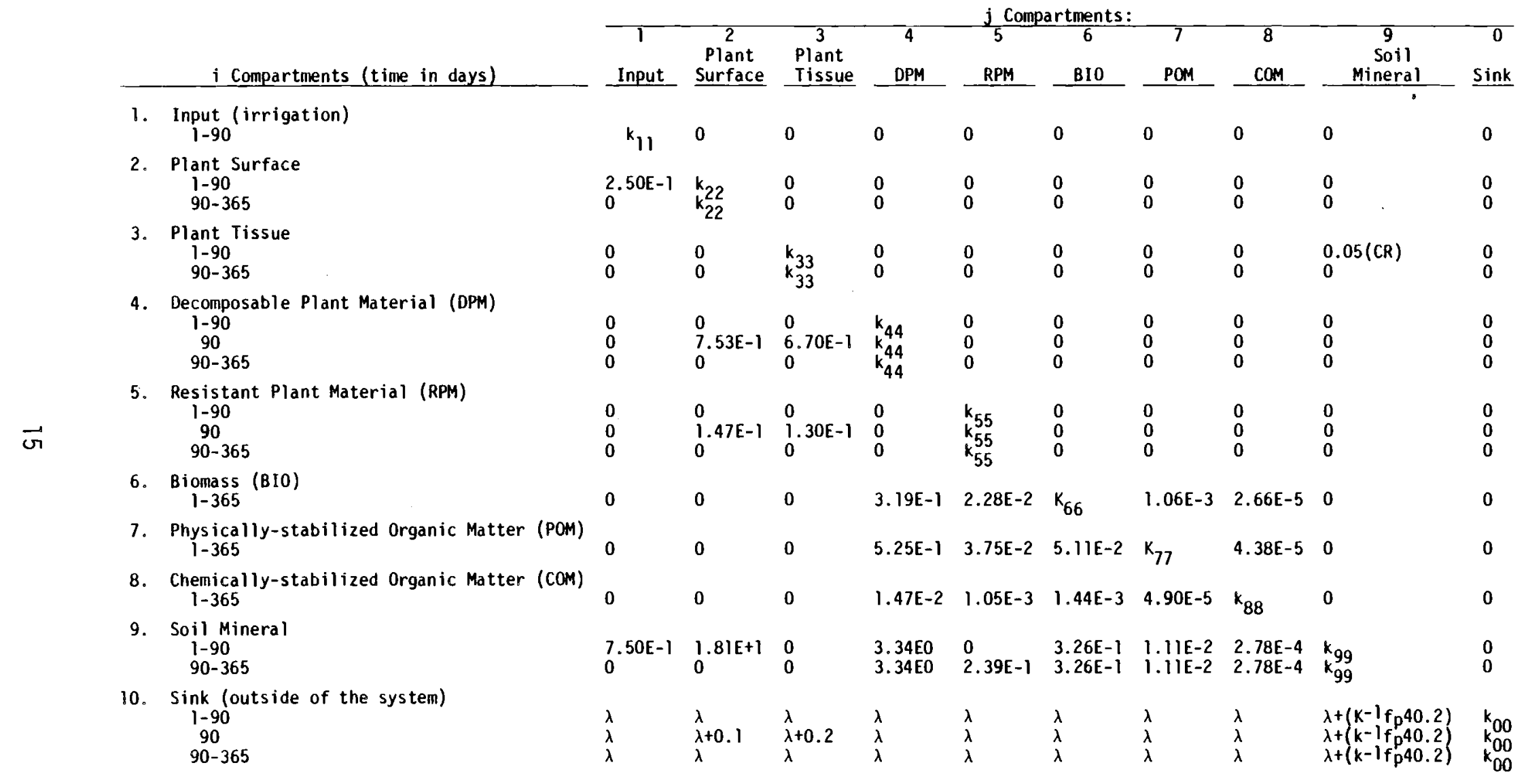

Notes: $2.50 \mathrm{E}-1=2.50 \times 10^{-1}$.

$C R=$ Concentration ratio (wet vegetation to dry soil)

$\lambda=$ Physical decay constant of the radionuclide $(0.693 /$ physical half-life), if the input is constant, $\lambda 01=0$.

$f_{p}=$ Fractional overwatering rate. 
The composite model, named CROPRE, was evaluated using the Euler technique (Scarborough 1965) to numerically approximate the solution of the differential equation that describes the transfer of materials between compartments. Time was the driving function. As an example, the differential equation describing the instantaneous rate of change in Compartment 4 is

$$
\frac{d Q_{4}}{d t}=k_{42} Q_{2}+k_{43} Q_{3}-k_{64} Q_{4}-k_{74} Q_{4}-k_{84} Q_{4}-k_{94} Q_{4}-k_{04} Q_{4}
$$

The general form becomes

$$
\frac{d Q_{i}}{d t}=\sum_{j=1}^{N}\left(k_{i j} Q_{j}-k_{j i} Q_{j}\right)
$$

where $N=$ number of compartments $(N=10)$.

If $k_{j j}$ equals the negative sum of all of the existing transfer coefficients that lead into Compartment $i$, as

$$
k_{j j}=-\sum_{\substack{i=1 \\ i \neq j}}^{N} k_{i j}
$$

then Equation (10) can be written as:

$$
\frac{d Q_{i}}{d t}=\sum_{j=1}^{N} k_{i j} Q_{j}
$$

The general equation used to numerically evaluate the differential expressions is

$$
Q(t+\Delta t)=Q(t)+\Delta t \frac{d Q}{d t}
$$


The value of $Q$ at time $t+\Delta t$ is approximated by adding the product of $\Delta t$ times the instantaneous rate of change, $\frac{d Q}{d t}$, to the amount that was present at time $t$. When Equations (11) and (12) are combined, the general form becomes

$$
Q_{j}(t+\Delta t)=Q_{j}(t)+\Delta t\left(\sum_{j=1}^{N}\right) k_{i j} Q_{j}
$$

Equation (13) is numerically evaluated at each time interval $(\Delta t)$ by first estimating the instantaneous rate of change [Equation (11)] using each of the $Q_{j}(t)$ values. The instantaneous rate of change times $\Delta t$ is then added to each $Q_{j}(t)$ value to estimate each $Q_{j}(t+\Delta t)$. The approximated values in each compartment become closer to the true value as $\Delta t$ approaches zero. The lower limit of $\Delta t$ is restricted by the computing costs associated with making the time interval smaller and smaller. Conversely, $\Delta t$ must not exceed a value in such a way that the product of $\Delta t$ and the largest $k_{i j}$ value is greater than 1.0. A benefit of using this technique is that the values of the transfer coefficients can be changed according to the time of the year.

The value of the Input Compartment was kept constant or only changed according to:

$$
Q_{1}(t)=Q_{1}(0) e^{-\left[\left(0.693 / T_{p}\right)(t)\right]}
$$

where $T_{P}=$ physical half-life of the radionuclide.

\section{ASSUMPTIONS:}

Many of the assumptions that were made in the development of the CROPRE model were taken from Burkholder et al. (1975) and ERDA (1975). The following list summarizes the assumptions used in this model:

- The input is from sprinkler irrigation.

- The initial concentration of a radionuclide in the water is 1.0 unit of activity $(U O A) / \ell$ water. 
- The crops are irrigated at $150 \mathrm{l} / \mathrm{m}^{2} \cdot$ month.

- The growing season lasts for 90 days $(0.25 \mathrm{yr})$.

- The vegetation is a grain crop such as wheat or barley.

- The fraction of the contaminant deposited on the vegetative surface is 0.25 ; the remaining portion is deposited directly onto the soil surface.

- The portion of contaminant on the vegetative surface is weathered to the soil surface with an environmental half-time of 14 days.

- The biomass of the vegetation is $2.8 \mathrm{~kg}$ wet weight $/ \mathrm{m}^{2}$, divided equally between the above- and below-ground portions.

- Twenty percent of the total plant biomass, or $0.56 \mathrm{~kg}$ wet weight $/ \mathrm{m}^{2}$, is harvested at the end of the 90-day growing season. The remaining $2.24 \mathrm{~kg}$ wet weight/ $\mathrm{m}^{2}$ are added to the soil organic matter pool.

- The concentration of the radionuclide, due to root uptake, is equal in the shoots, roots, and seeds of the vegetation.

- The translocation ratio, which describes the plant's ratio of radionuclide concentration from direct deposition only to the concentration in the seeds of the plant, is 0.1 .

- The plow depth is $15 \mathrm{~cm}$. The root-zone does not extend below $15 \mathrm{~cm}$; anything below this depth is lost from the system.

- The soil surface density is $224 \mathrm{~kg}$ dry weight $/ \mathrm{m}^{2}$.

- The soil type is typical of the arid western United States.

- The water-holding capacity of the soil is $20 \%$.

- The transfer of material from the Soil Mineral Compartment to the plant roots can be approximated using Equation (7), $\mathrm{k}_{39}=0.05 \mathrm{CR} \mathrm{yr}^{-1}$. The concentration ratio (CR) values are taken from ERDA (1975, page III-A-52). Other CR values, obtained from various sources, are also used. 
- A11 of the material in the soit mineral compartment is available for either plant uptake, described by $k_{39}$, or downward movement away from the root-zone by water percolation if the soil/plant system is overwatered. The downward movement is approximated by $k_{09}$, Equation (9), and it depends on the overwatering rate $\left(f_{p}\right)$ and the sorption equilibrium constant $\left(K^{-1}\right)$.

- The decomposition of soil organic matter and the release of radionuclides to the Soil Mineral Compartment follows the model reported by Jenkinson and Rayner (1977) that describes the turnover of carbon. 
.

.

. 


\section{RESULTS AND DISCUSSION}

A computer program ${ }^{(a)}$ was written to numerically evaluate the CROPRE model. As we noted previously, time $(t)$ was the driving function and the lower limit of $\Delta t$ governed the amount of time required to evaluate the model. Because of the relative short half-time (15 days) associated with the weathering of material from the plants' surfaces $\left(k_{92}\right)$, the value of $\Delta t$ could not be less than 0.05 years. However, in certain instances, it was necessary to evaluate the model for time periods greater than 10,000 years to obtain the maximum radionuclide concentration in the seeds and the time at which it occurred.

The input rate of the model for a particular radionuclide was usually decreased according to the physical half-life of the radionuclide starting with an initial water concentration of $1.0 \mathrm{UOA} / \mathrm{l}$ at $t=0$. However, for certain short-lived radionuclides that occur in decay chains, the program was run with a constant input. For selected radionuclides, the model was evaluated using different concentration ratio $(C R)$ values. In all instances, the model was run for each element, first with an input rate that simulated a $10 \%$ overwatering rate $\left(165 \mathrm{l} / \mathrm{m}^{2} \cdot\right.$ month) and again without overwatering $\left(150 \mathrm{l} / \mathrm{m}^{2} \cdot\right.$ month)

Radionuclide concentrations in seeds were also estimated with the same Fifty-Year Accumulation Method (FYAM) used by Burkholder et al. (1975). These values were compared with the estimates from CROPRE. The FYAM values were calculated by considering the contributions from the plant surface deposition route, as well as from the root uptake pathway. The concentration of radionuclides in the seeds from surface contamination $\left(C_{D}\right)$ was estimated by:

$$
C_{D}=\frac{I f_{p} f_{t}}{M_{v} k_{v}}\left(1-e^{-k_{v} t^{-}}\right)
$$

where, I, corrected for physical decay according to Equation (14), equals the input rate [Equation (1)] at $t=50 \mathrm{yr}$.

(a) See Appendix page A.1. 
where $I=\left(1+f_{W}\right)\left(1800 \mathrm{UOA} / \mathrm{m}^{2} \cdot \mathrm{yr}\right) \mathrm{e}^{-\left[\left(0.693 / T_{p}\right)(50 \mathrm{yr})\right]}$

$$
\begin{aligned}
f_{W}=\text { fractional overwatering rate, and } \\
T_{p}=\text { physical half-life of the radionuclide }(y r) ; \\
f_{p}=\text { fraction of the contaminant deposited on the plant surface initially } \\
\quad\left(f_{p}=0.25\right) ; \\
f_{T}=\text { translocation ratio that describes the ratio of the concentration in } \\
\quad \text { the seeds to the concentration in the total plant }\left(f_{T}=0.1\right) ; \\
M_{v}=\text { biomass of the vegetation }\left(M_{v}=1.4 \mathrm{~kg} \text { wet vegetation } / \mathrm{m}^{2}\right) ; \\
k_{v}=0.693 / T_{E}\left(T_{E}=\right.\text { environmental half-time of contaminants on the surface } \\
\text { of plants, and } \left.T_{E}=0.038 \mathrm{yr}\right) ; \text { and } \\
t^{-}=\text {length of growing season }=0.25 \mathrm{yr} .
\end{aligned}
$$

Since the environmental half-time $\left(T_{E}\right)$ is relatively short compared to the length of the growing season, $C_{D}$ can be calculated as:

$$
\begin{aligned}
& C_{D}=\frac{\left(1+f_{W}\left(1800 \cup 0 A / \mathrm{m}^{2} \cdot \mathrm{yr}\right)(0.25)(0.1)\right.}{\left(1.4 \mathrm{~kg} / \mathrm{m}^{2}\right)(0.693 / 0.038 \mathrm{yr})} e^{-\left[\left(0.693 / T_{p}\right)(50 \mathrm{yr})\right]} \\
& C_{D}=\left(1+f_{W}\right)(1.76 \mathrm{UOA} / \mathrm{kg}) \mathrm{e}^{-\left(34.7 \mathrm{yr} / T_{p}\right)}
\end{aligned}
$$

The plant tissue concentration $\left(C_{T}\right)$ was estimated as:

$$
C_{T}=\frac{I\left\{1-e^{\left.-\left[\left(0.693 / T_{p}\right)(50 y r)\right]\right\}}\right.}{M_{S}\left(0.693 / T_{p}\right)} \text { (CR) }
$$

where $I=$ initial input rate

$$
\begin{aligned}
& =\left(1+f_{W}\right)\left(150 \mathrm{l} / \mathrm{m}^{2} \cdot \text { month }\right)(3 \text {-month growing season } / \mathrm{yr})(1 \mathrm{UOA} / \mathrm{l}) \\
& =\left(1+f_{W}\right)\left(450 \mathrm{UOA} / \mathrm{m}^{2} \cdot \mathrm{yr}\right) ; \\
M_{S} & =\text { soil surface density }-224 \mathrm{~kg} \text { dry soil } / \mathrm{m}^{2} ; \text { and } \\
C_{R} & =\text { concentration ratio }(\mathrm{kg} \text { dry soi } 1 / \mathrm{kg} \text { wet vegetation }) .
\end{aligned}
$$


All of the contaminant was applied directly onto the soil surface for a total of 50 years. After 50 years of continuous input, the plant tissue concentration would be:

$$
\begin{aligned}
& C_{T}=\frac{\left(1+f_{W}\right)\left(450 \mathrm{UOA} / \mathrm{m}^{2} \cdot \mathrm{yr}\right)}{224 \mathrm{kgdry} \text { soi } 1 / \mathrm{m}^{2}\left(0.693 / T_{p}\right)}(C R)\left\{1-\mathrm{e}^{\left.-\left[\left(0.693 / T_{p}\right)(50 \mathrm{yr})\right]\right\}}\right. \\
& C_{T}=(2.90 \mathrm{UOA} / \mathrm{kg} \text { dry soil } \cdot \mathrm{yr})\left(1+f_{W}\right)(C R)\left(T_{p}\right)\left[1-\mathrm{e}^{-\left(34.7 \mathrm{yr} / T_{p}\right)}\right]
\end{aligned}
$$

The seeds were assumed to have the same concentration as the Plant Tissue Compartment. The total radionuclide concentration in the seed $\left(C_{s}\right)$ from both surface deposition and root uptake was estimated by summing Equations (15) and (16):

$$
\begin{aligned}
C_{S}= & C_{D}+C_{T}=\left(1+f_{w}\right)\left\{(1.76 \mathrm{UNA} / \mathrm{kg}) \mathrm{e}^{-\left(34.7 \mathrm{yr} / T_{p}\right)}+(2.90 \mathrm{UOA} / \mathrm{kg} \cdot \mathrm{yr})\right. \\
& \left.(C R)\left(T_{p}\right)\left\{1-\mathrm{e}^{-\left(34.7 \mathrm{yr} / T_{p}\right)}\right)\right\}
\end{aligned}
$$

Figure 4 presents an example of the buildup of radionuclides in the compartments outlined in Figure 3. The example given is for technetium-99 ( ${ }^{99} \mathrm{TC}$ ), which has a physical half-life of $2.1 \times 10^{5} \mathrm{yr}$. The system was not overwatered, and the $C R$ value was set equal to 0.25 . Because the system was not overwatered, the radionuclide was not percolated away from the root-zone. The contaminant was lost from the system only by physical decay and by removal of the seeds at harvest. The curve entitled "cumulative input to soil" (Figure 4) shows what would happen to the soil's radionuclide concentration if: 1) all of the contaminant were applied only to the soil,2) there were no plant uptake, and 3) the only loss were by physical decay. This curve and the "soil mineral" curve differ by the material lost through physical decay, the material harvested, and the fraction remaining in the organic matter pool. The difference 


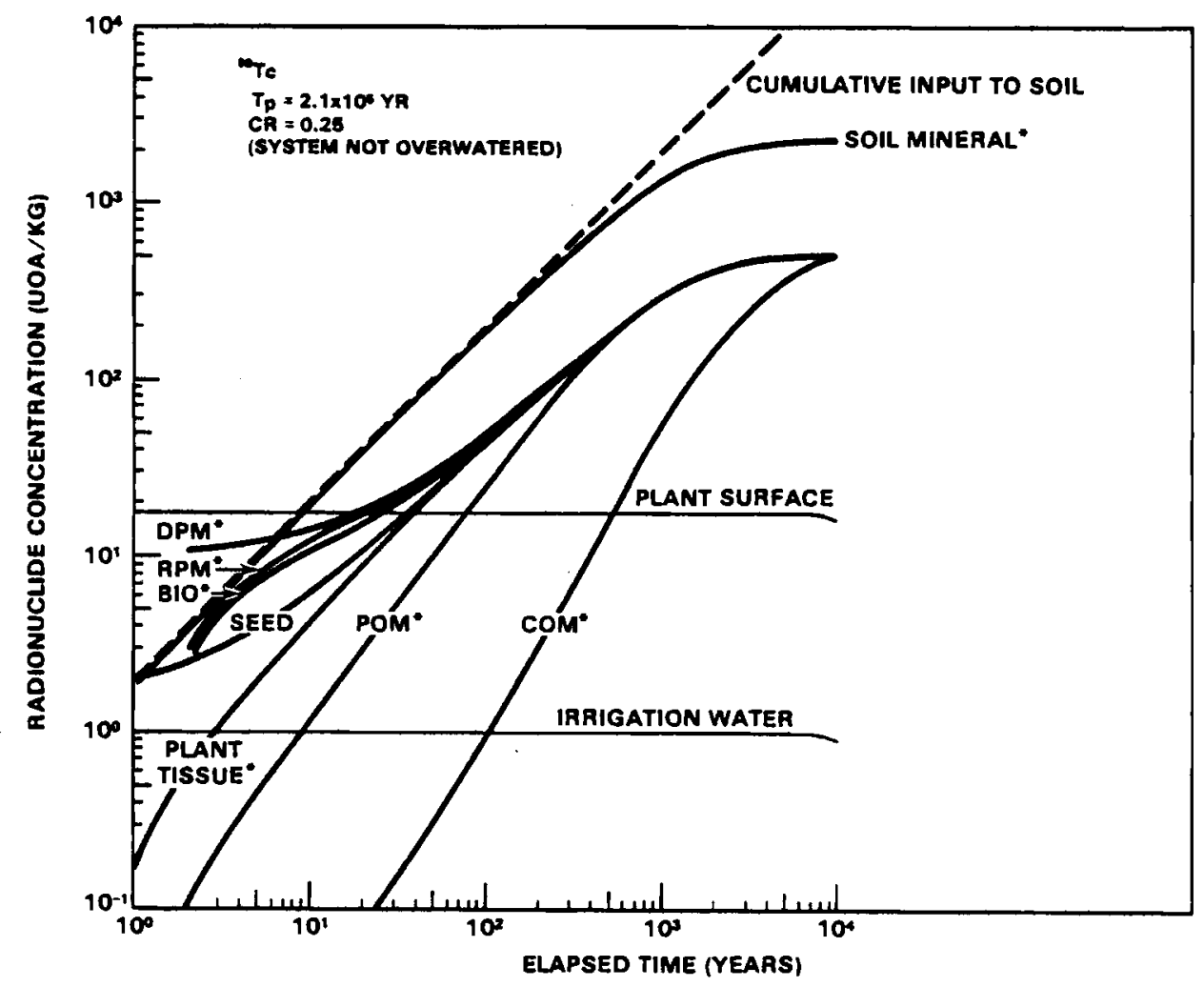

-See figuae 3. PAge 13

FIGURE 4. Long-Term Accumulation of ${ }^{99} \mathrm{TC}$ in Various Compartments of a Crop Plant System

increases as more of the contaminant is incorporated into the Soil organic Matter Compartments or is lost by harvesting. The Soil Organic Matter Compartments, especialiy the Chemically-stabilized Organic Matter Compartment with its 2000-year half-time, strongly affect the amount of time required for the system to reach equilibrium. For ${ }^{99} \mathrm{Tc}$, as well as several other radionuclides, equilibrium was obtained at about 10,000 years. This is about a factor of five larger than the half-time of the Chemically-stabilized Organic Matter Compartment. However, for radionuclides with very long half-lives and smal1 CR values, the seed concentration was still increasing at $t=30,000 \mathrm{yr}$.

For the example presented in Figure 4, the Plant Surface Compartment has the greatest effect on the concentration of radionuclides in the seeds during the first few years. The weathering half-time of material from the plant 
surface is 14 days, allowing this compartment to come to an equilibrium value (18 UOA $/ \mathrm{kg}$ ) within each growing season. When the translocation ratio is 0.1 , the resulting seed concentration is $1.8 \mathrm{UOA} / \mathrm{kg}$. Then, as the radionuclide level in the Soil Mineral Compartment increases (primarily from continual irrigation), root uptake (the Plant Tissue Compartment) becomes increasingly important. The Decomposable Plant Material and the Resistant Plant Material Compartments equilibrate at about $t=40 \mathrm{yr}$. These two compartments equilibrate with the Biomass Compartment and the Plant Tissue Compartment at $t \simeq 500 \mathrm{yr}$, the Physically-stabilized Organic Matter Compartment at $t=1,000 \mathrm{yr}$ and the Chemically-stabilized Organic Matter Compartment at $t=10,000 \mathrm{yr}$. The radionuclide concentration value for seeds is practically the same as the value for the Plant Tissue Compartment after about 300 years: because the root uptake route translocates more ${ }^{99} \mathrm{Tc}$ to the seeds than the plant surface route. After about 10,000 years, the concentration in the seeds, as well as in all the other compartments, decreases at the physical decay rate of the radionuclide.

Technetium-99 was used to demonstrate the effect that overwatering the system has on the equilibium concentrations of radionuclides in seeds. The sorption equilibrium constant $\left(\mathrm{K}^{-1}\right)$ was set equal to 1.0 . When the $C R$ value was 0.25 (as presented in Figure 5 ), the equilibrium value was $510 \mathrm{UOA} / \mathrm{kg}$ seed at $t \simeq 6,600 \mathrm{yr}$ when the system was not overwatered and only $2.4 \mathrm{UOA} / \mathrm{kg}$ seed at $t \simeq 6 \mathrm{yr}$ when it was overwatered. The equilibrium value was much lower when the system was overwatered, primarily because of the sorption equilibrium constant $\left(\mathrm{K}^{-1}\right)$ value. With $\mathrm{K}^{-1}$ equal to 1.0 , the contaminant moves downward through the soil profile at the same velocity as water. Therefore, a proportionally larger fraction of the material is lost from the system and becomes unavailable for root uptake. For comparison, the FYAM value [from Equation (17)] with an irrigation rate of $150 \mathrm{l} / \mathrm{m}^{2} \cdot$ month was $27 \mathrm{UOA} / \mathrm{kg}$ seed, and it was $29 \mathrm{UOA} / \mathrm{kg}$ seed when the input was $165 \mathrm{l} / \mathrm{m}^{2} \cdot$ month. When the system was overwatered, the FYAM value was a factor of $12(29 / 2.4)$ larger than the maximum estimate obtained by CROPRE. However, without overwatering, the CROPRE value was 19-fold larger than the FYAM estimate. 


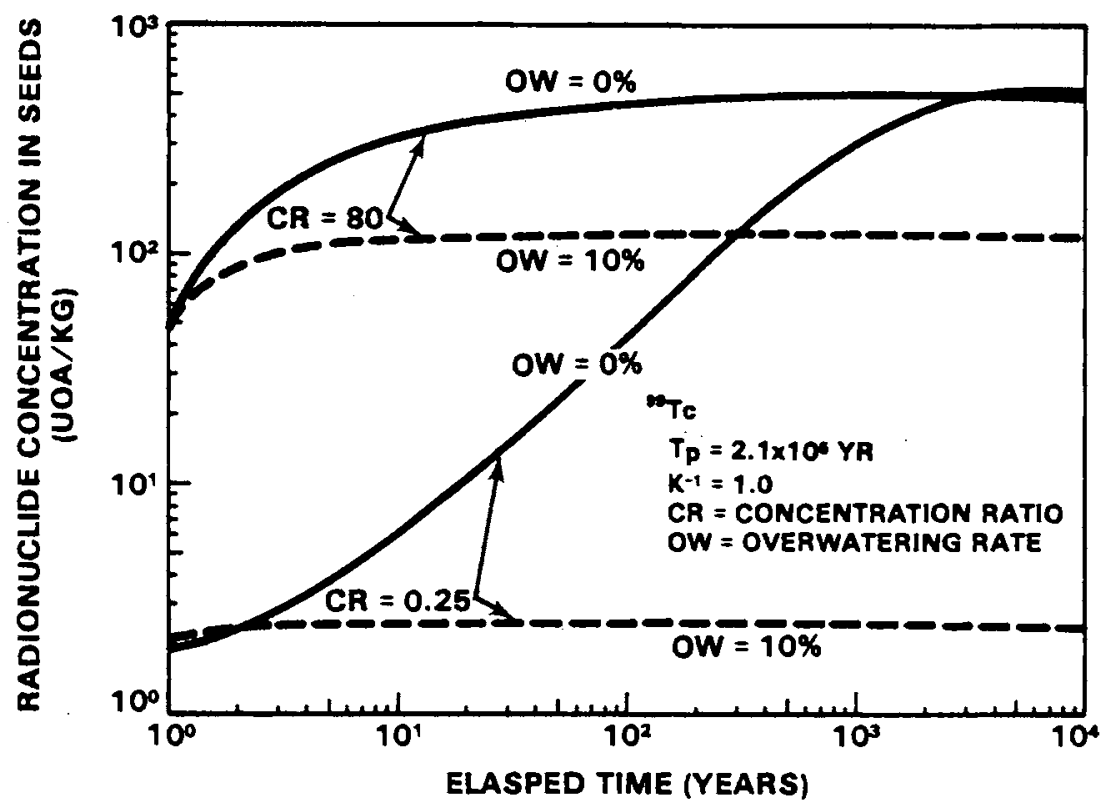

FIGURE 5. The Effect of Varying Irrigation Regimes and and Concentration Ratios on the Accumulation of ${ }^{99} \mathrm{Tc}$ in Seeds as a Function of Time

If the $C R$ value is increased from 0.25 to 80 , the resulting equilibrium value is $120 \mathrm{UOA} / \mathrm{kg}$ seed (at $t \simeq 260 \mathrm{yr}$ ) when the system is overwatered compared to $500 \mathrm{UOA} / \mathrm{kg}$ seed (at $t \simeq 600 \mathrm{yr}$ ) when it is not overwatered. The corresponding FYAM estimates are $8,000 \mathrm{UOA} / \mathrm{kg}$ seed for no overwatering and $8,800 \mathrm{UOA} / \mathrm{kg}$ seed for $10 \%$ overwatering; both estimates are larger than the corresponding equilibrium values from CROPRE. The overwatering causes more of the material to percolate out of the root-zone and become unavailable for root uptake. This results in a four-fold reduction in radionuclide concentration in seeds compared to the results when the system is not overwatered.

When the $C R$ value was set equal to 0.25 , the overwatering equilibrium estimate was a factor of 210 lower than when the system was not overwatered. The differences were reduced as the $C R$ value was increased since more of the radionuclide became incorporated into the Plant Tissue Compartment (and hence, into the Soil Organic Matter Compartments) as time passed and as a lower proportion percolated away from the root-zone. Then, as organic matter was broken down, more of the contaminant became available for uptake by succeeding generations of plants. 
When the system was not overwatered, increasing the $C R$ value did not necessarily increase the equilibrium value. The equilibrium value was $510 \mathrm{UOA} / \mathrm{kg}$ seed when the $C R$ value was equal to 0.25 , and it was even reduced slightly to $500 \mathrm{UOA} / \mathrm{kg}$ seed when the $C R$ value was 80 . With the higher $C R$ value, proportionally more of the contaminant was removed from the system when the seeds were harvested each year, making less of the radionuclide available in succeeding years. This is further illustrated in Figure 6 for plutonium-239 $\left({ }^{239} \mathrm{Pu}\right)$, which has a physical half-life $\left(T_{p}\right)$ of $2.4 \times 10^{4} \mathrm{yr}$. The system was not overwatered for this example. The $C R$ value was started initially at 0.00025 and then increased by a factor of 10 for each succeeding run. The maximum equilibrium value, $510 \mathrm{UOA} / \mathrm{kg}$ seed, was observed with the highest $\mathrm{CR}$ value, 25. For smaller $C R$ values, the smaller equilibrium estimates are probably more a function of the physical half-time of ${ }^{239} \mathrm{Pu}$ than the $C R$ values. The $C R$ value affects the rate at which the Plant Tissue Compartment equilibrates. For CR values smaller than about 0.01 , the seeds had not reached an equilibrium value within 30,000 years.

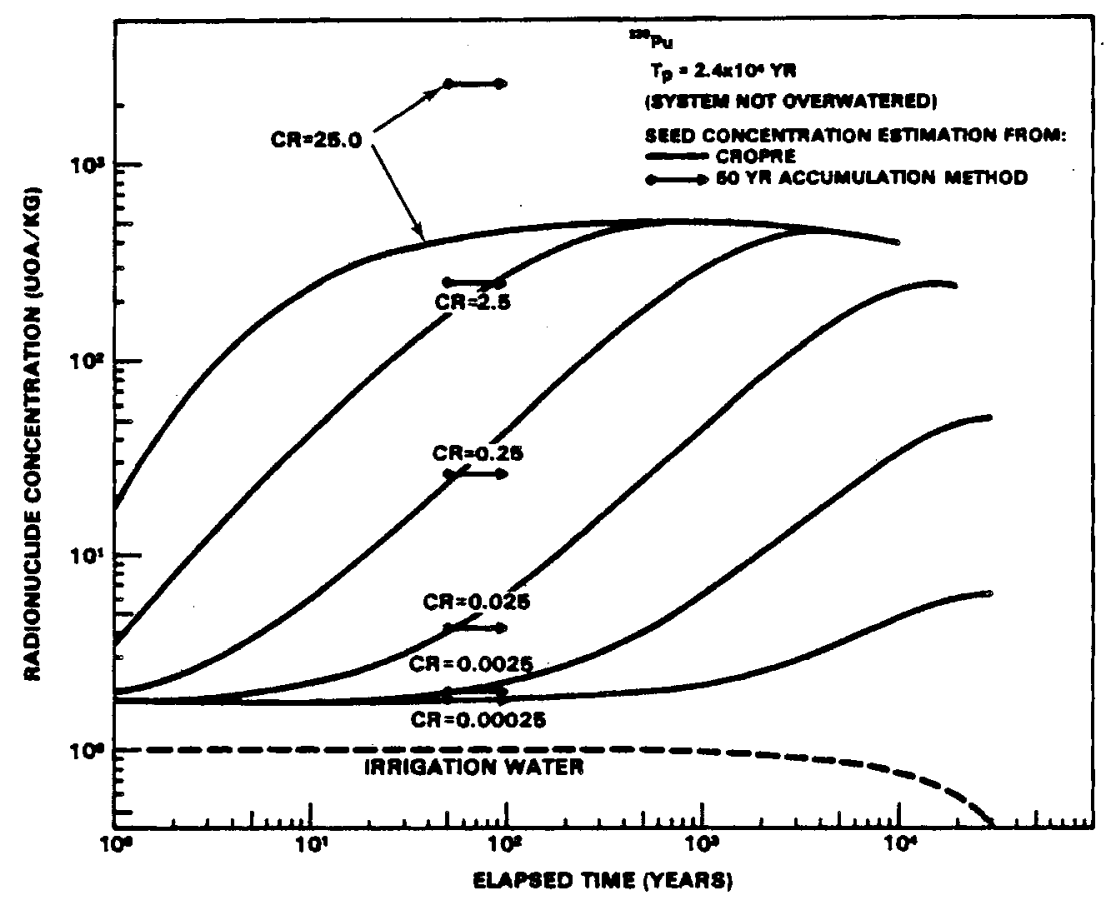

FIGURE 6. The Effect of Changing the Concentration Ratio Value on the Accumulation of ${ }^{23} \mathrm{Pu}$ in Seeds When the System is not Overwatered 
A comparison of the FYAM method with the CROPRE method of predicting radionuclide concentration in seeds is presented in Figure 6 . In all of the cases, the estimate from CROPRE for no overwatering at $t=50 \mathrm{yr}$ was less than the value derived using the Fifty-Year Accumulation Method. This is to be expected with the CROPRE model because it considers that a certain fraction of the contaminant is incorporated into the Organic Matter Compartments or lost from the system during harvest. However, except for when the CR values exceed 2.5, the CROPRE estimates exceed the corresponding FYAM values within 88 years. The resulting equilibrium (or maximum value if equilibrium was not obtained) from CROPRE exceeded the FYAM estimates by as much as a factor of 60 when the $C R$ value was set at 0.025 .

The results of evaluating the CROPRE model for selected radionuclides are summarized in Table 3. The radionuclides were selected on the basis of their migration rates in soil and the relative magnitudes of their predicted doses as reported by Burkholder et a1. (1975). Table 3 also contains estimates of the maximum concentration of each radionuclide in seeds and the time at which it occurred. Included are examples where the irrigation rate produced no overwatering, as well as situations with a 10\% overwatering rate. Table 3 contains values for the corresponding Fifty-Year Accumulation Method estimates and the times required for the CROPRE values to equal the FYAM estimates. If the CROPRE values did not reach or exceed the FYAM estimates, the corresponding values were omitted in the table.

When the system was not overwatered, the seed concentration estimates from CROPRE usually equaled or exceeded the FYAM value within 88 years. The average amount of time, 57 years (excluding palladium-107), required for the CROPRE estimates to equal the FYAM values generally increased as the CR values were increased. The CROPRE estimate for ${ }^{107} \mathrm{Pd}$, which has a $C R$ value of 5.0 , equaled the FYAM estimate at $t=370 \mathrm{yr}$, while radionuclides with even larger CR values never reached the FYAM values. Of the 39 runs made on 27 radionuclides, 37 had maximum CROPRE estimates larger than the corresponding FYAM values. These maxima, which usually occurred at $t>1,000 \mathrm{yr}$, ranged up to 120 times as great as the FYAM values. The time period required for 
TABLE 3. Comparison of the Concentrations of Radionuclides in Seeds Predicted by the Fifty-Year Accumulation Method (FYAM) and by the Long-Term Accumulation Method (CROPRE)

\begin{tabular}{|c|c|c|c|c|c|c|c|c|c|c|c|}
\hline \multirow[b]{2}{*}{ I sotope } & \multirow[b]{2}{*}{$T_{p}(y r)$} & \multirow[b]{2}{*}{$R$} & \multirow[b]{2}{*}{$K^{-1}$} & \multicolumn{4}{|c|}{$\frac{\text { Not Overwatered }\left(150 \mathrm{e}^{2} \mathrm{~m}^{2} \cdot \text { month }\right)}{\text { from CROPRE }}$} & \multicolumn{4}{|c|}{$\frac{\text { Overwatered } 10 \%\left(165 \mathrm{l} / \mathrm{m}^{2} \cdot \text { month }\right)}{\text { from CROPRE }}$} \\
\hline & & & & $\begin{array}{c}\text { FYAM } \\
(\cup O A / \mathrm{kg}) \\
\end{array}$ & $\begin{array}{l}\text { Yr to } \\
\text { Equal } \\
\text { FYaM } \\
\end{array}$ & $\begin{array}{c}\text { Max. } \\
\text { Value } \\
\text { (UOA/kg) }\end{array}$ & $\begin{array}{c}\text { Yr of } \\
\text { Maximum } \\
\text { Occurrence }\end{array}$ & $\begin{array}{c}\text { FYAM } \\
\text { (UOA/kg) }\end{array}$ & $\begin{array}{l}\text { Yr to } \\
\text { Equa ] } \\
\text { FYAM } \\
\end{array}$ & $\begin{array}{c}\text { Max. } \\
\text { Value } \\
\text { (UOA/kg) }\end{array}$ & $\begin{array}{c}\text { Yr of } \\
\text { Maximum } \\
\text { Occurrence }\end{array}$ \\
\hline $1_{\mathrm{Be}}$ & $1.6 \times 10^{6}$ & 0.0004 & 0.003 & 1.8 & 50 & $23.0^{(a)}$ & 30,000 & 2.0 & 50 & 2.2 & 1,400 \\
\hline${ }^{41} \mathrm{Ca}$ & $1.3 \times 10^{5}$ & 0.036 & 0.01 & 5.4 & 56 & 440.0 & 24,000 & 5.9 & 81 & 9.0 & 580 \\
\hline${ }^{59} \mathrm{Ni}$ & $8.0 \times 10^{4}$ & 0.019 & 0.002 & 3.7 & 56 & $230.0^{(a)}$ & 10,000 & 4.0 & 66 & 14.0 & 1,500 \\
\hline${ }^{63} \mathrm{Ni}$ & $1.0 \times 10^{2}$ & 0.019 & 0.002 & 2.9 & 85 & 2.6 & 85 & 3.1 & $\cdots$ & 2.7 & 63 \\
\hline${ }^{79} \mathrm{Se}$ & $6.5 \times 10^{4}$ & 1.3 & 0.01 & 140.0 & 69 & 510.0 & 1,500 & 150.0 & 130 & 180.0 & 560 \\
\hline $87_{\mathrm{Rb}}$ & $4.7 \times 10^{10}$ & 0.13 & 0.002 & 14.0 & 57 & 530.0 & 14,000 & 16.0 & 60 & 110.0 & 2,100 \\
\hline${ }^{90} \mathrm{Sr}$ & $2.9 \times 10^{1}$ & 0.2 & 0.01 & 12.0 & -- & 6.1 & 35 & 13.0 & - & 5.8 & 29 \\
\hline${ }^{90} s r$ & $2.9 \times 10^{1}$ & 2.0 & 0.01 & 120.0 & -- & 46.0 & 35 & 130.0 & -- & 44.0 & 31 \\
\hline${ }^{93} \mathrm{zr}$ & $9.5 \times 10^{5}$ & 0.00017 & 0.0001 & 1.8 & 50 & $11.0^{(a)}$ & 30,000 & 2.0 & 50 & $5.0^{(a)}$ & 30,000 \\
\hline${ }^{93}$ Mo & $3.0 \times 10^{3}$ & 0.13 & 0.04 & 15.0 & 57 & 200.0 & 2,400 & 16.0 & -- & 8.0 & 110 \\
\hline${ }^{99} \mathrm{TC}$ & $2.1 \times 10^{5}$ & 0.25 & 1.0 & 27.0 & 58 & 510.0 & 6,600 & 29.0 & -- & 2.4 & 6 \\
\hline${ }^{99} \mathrm{TC}$ & $2.1 \times 10^{5}$ & 80.0 & 1.0 & $8,000.0$ & + & 500.0 & 660 & $8,800.0$ & $\cdots$ & 120.0 & 260 \\
\hline${ }^{107} \mathrm{Pd}$ & $6.5 \times 10^{6}$ & 5.0 & 0.0009 & 502.0 & 370 & 530.0 & 10,000 & 552.0 & - - $^{(a)}$ & $550.0^{(d)}$ & 10,000 \\
\hline $113 m_{c d}$ & $1.4 \times 10^{1}$ & 0.3 & 0.0004 & 11.0 & $\cdots$ & 4.4 & 17 & 12.0 & -- & 4.8 & 17 \\
\hline${ }^{126_{S m}}$ & $1.0 \times 10^{5}$ & 0.0025 & 0.0009 & 2.0 & 52 & $100.0^{(a)}$ & 30,000 & 2.2 & 53 & 7.1 & 4,600 \\
\hline $129_{I}$ & $1.6 \times 10^{7}$ & 0.02 & 1.0 & 3.8 & 56 & $460.0^{(a)}$ & 30,000 & 4.1 & + & 2.0 & 1 \\
\hline${ }^{135} \mathrm{Cs}$ & $2.3 \times 10^{6}$ & 0.003 & 0.001 & 2.1 & 52 & $140.0^{(a)}$ & 30,000 & 2.3 & 54 & 7.8 & 6,200 \\
\hline${ }^{135} \mathrm{Cs}$ & $2.3 \times 10^{6}$ & 0.01 & 0.001 & 2.8 & 55 & $340.0^{(a)}$ & 30,000 & 3.0 & 57 & 21.0 & 5,600 \\
\hline $166 \mathrm{~m}_{\mathrm{Ho}}$ & $1.2 \times 10^{3}$ & 0.0026 & 0.0004 & 2.0 & 51 & 3.7 & 1,300 & 2.2 & 53 & 3.5 & 870 \\
\hline $210_{\mathrm{Pb}}$ & $2.0 \times 10^{1}$ & 0.068 & 0.00006 & 3.6 & -- & 2.1 & 15 & 3.9 & -- & 2.3 & 14 \\
\hline $210_{\mathrm{Pb}}$ & (b) & 0.068 & 0.00006 & 12.0 & 88 & 5.3 & 180 & 13.0 & 75 & 5.8 & 200 \\
\hline${ }^{226} \mathrm{Ra}$ & $1.6 \times 10^{3}$ & 0.00031 & 0.002 & 1.7 & -. & 1.8 & 1 & 1.9 & -- & 2.0 & 1 \\
\hline${ }^{226} \mathrm{Ra}$ & (b) & 0.00031 & 0.002 & 1.8 & 50 & 3.1 & 12,000 & 2.0 & 50 & 2.2 & 1,700 \\
\hline${ }^{232} \mathrm{Th}$ & $1.4 \times 10^{10}$ & 0.0042 & 0.00002 & 2.2 & 53 & $190.0^{(a)}$ & 30,000 & 2.4 & 54 & $160.0^{(a)}$ & 30,000 \\
\hline${ }^{231} \mathrm{~Pa}$ & $3.2 \times 10^{4}$ & 0.0025 & 0.0006 & 2.0 & 52 & $64.0^{(a)}$ & 30,000 & 2.2 & 53 & 8.7 & 5,200 \\
\hline $233_{U}$ & $1.6 \times 10^{5}$ & 0.0025 & 0.00007 & 2.0 & 51 & $110.0^{(a)}$ & 30,000 & 2.2 & 51 & $52.0^{\langle a\rangle}$ & 30,000 \\
\hline${ }^{237} \mathrm{~Np}$ & $2.1 \times 10^{6}$ & 0.0025 & 0.01 & 2.0 & 51 & $120.0^{(a)}$ & 30,000 & 2.2 & 71 & 2.4 & 430 \\
\hline${ }^{237} \mathrm{~Np}$ & $2.1 \times 10^{6}$ & 0.25 & 0.01 & 27.0 & 58 & 520.0 & 8,500 & 29.0 & 86 & 47.0 & 670 \\
\hline${ }^{238} \mathrm{Pu}$ & $8.8 \times 10^{1}$ & 0.00025 & 0.0001 & 1.2 & $\cdots$ & 1.8 & 1 & 1.3 & -- & 1.9 & 1 \\
\hline${ }^{239} \mathrm{Pu}$ & $2.4 \times 10^{4}$ & 0.00025 & 0.0001 & 1.8 & 50 & $6.5^{(a)}$ & 30.000 & & & & \\
\hline${ }^{239} \mathrm{Pu}$ & $2.4 \times 10^{4}$ & 0.0025 & 0.0001 & 2.0 & 52 & $52.0^{(a)}$ & 30,000 & & & & \\
\hline${ }^{239} \mathrm{Pu}$ & $2.4 \times 10^{4}$ & 0.025 & 0.0001 & 4.2 & 56 & 250.0 & 16,000 & & & & \\
\hline${ }^{239} \mathrm{Pu}$ & $2.4 \times 10^{4}$ & 0.25 & 0.0001 & 27.0 & 58 & 450.0 & 3,900 & & & & \\
\hline${ }^{239} \mathrm{Pu}$ & $2.4 \times 10^{4}$ & 2.5 & 0.0001 & 250.0 & 87 & 510.0 & 780 & & & & \\
\hline${ }^{239} \mathrm{Pu}$ & $2.4 \times 10^{4}$ & 25.0 & 0.0001 & $2,500.0$ & -. & 510.0 & 490 & & & & \\
\hline${ }^{244} \mathrm{Pu}$ & $8.3 \times 10^{8}$ & 0.00025 & 0.0001 & 1.8 & 50 & $6.6^{(a)}$ & 30,000 & 2.0 & 50 & $15.0^{(\mathrm{a})}$ & 30,000 \\
\hline 243 AM & $7.4 \times 10^{3}$ & 0.00025 & 0.0001 & 1.8 & 50 & 2.6 & 6,100 & 2.0 & 50 & 2.5 & 3,600 \\
\hline $243 \mathrm{Am}$ & $7.4 \times 10^{3}$ & 0.0025 & 0.0001 & 2.0 & 54 & 18.0 & 8,800 & 2.2 & 54 & 14.0 & 6,500 \\
\hline${ }^{247} \mathrm{~cm}$ & $1.5 \times 10^{7}$ & 0.0025 & 0.0003 & 2.0 & 51 & 120.0 & 30,000 & 2.2 & 52 & 18.0 & 17,000 \\
\hline
\end{tabular}

(a) The predicted values were still increasing at the time listed.

(b) Input was kept constant. 
the CROPRE estimate to reach a maximum decreased as the CR value was increased. Generally, the ratio of the maximum CROPRE value to the FYAM estimate was inversely related to the half-life of the radionuclide and directly proportional to the CR values smaller than five. The maximum CROPRE estimate did not exceed the FYAM value when the $C R$ value was greater than about five or when the physical half-life was less than 100 years. Even if the input was kept constant, the maximum values for radionuclides with short half-lives did not exceed the FYAM estimates.

The sorption equilibrium constant $\left(\mathrm{K}^{-1}\right)$ had the greatest effect on the radionuclide concentrations obtained in seeds when the system was overwatered. Generally, if the value of $\mathrm{K}^{-1}$ was larger than about 0.01 , the maximum CROPRE value was less than the FYAM estimate. This also depended upon the half-life: short-lived radionuclides (<100 years) never exceeded the FYAM estimates, independent of the $\mathrm{K}^{-1}$ value; however, the 29 radionuclides that did exceed the FYAM estimates al1 did so within an average time period of about 62 years. When the system was overwatered, the maximum seed concentration averaged about a factor of 20 less than when the system was not overwatered, even though the input to the system was 10\% larger when the system was overwatered. The maximum CROPRE values were about a factor of 10 larger than the corresponding FYAM estimates.

The $C R$ value for strontium-90 $\left({ }^{90} \mathrm{Sr}\right)$ was increased by a factor of 10 from the 0.2 value listed in ERDA (1975) to more closely correspond to the estimates reported for arid western U.S. soils by Rediske and Selders (1953), C1ine (1956), Routson and Cataldo (1978), and Cataldo et al. (1978). With either CR value, the resulting maximum CROPRE estimate was still less than the corresponding FYAM value. The maximum CROPRE estimates were only increased by a factor of about eight for either water regime since increasing the CR values caused a larger fraction of the ${ }^{90} \mathrm{Sr}$ to become incorporated in the Organic Matter Compartments.

The $C R$ value for ${ }^{99}$ Tc was increased from 0.25 to 80 to reflect the high CR values (ranging up to 1,000 on a dry vegetation to dry soil basis) reported by Wildung, Cataldo, and Garland (1976) and Routson and Cataldo (1977). With 
the plant biomass and surface soil density values used in this model, the CR value cannot exceed 80 . If all of that radionuclide in the soil at the beginning of the growing season (expressed as $X U O A / \mathrm{m}^{2}$ ) were taken up by the plants, then the $C R$ value would be:

$C R=\frac{\left(X \cup O A / \mathrm{m}^{2}\right) /\left(2.8 \mathrm{~kg} \text { wet vegetation } / \mathrm{m}^{2}\right)}{\left(X \cup 0 A / \mathrm{m}^{2}\right) /\left(224 \mathrm{~kg} \mathrm{dry} \text { so } i 1 / \mathrm{m}^{2}\right)}=80 \mathrm{~kg}$ dry soil $/ \mathrm{kg}$ wet vegetation

When the CR value was increased from 0.25 to 80 , the FYAM estimates were increased nearly proportionally (from 27 to $8,000 \mathrm{UOA} / \mathrm{kg}$ wet vegetation when the system was not overwatered and from 29 to $8,800 \mathrm{UOA} / \mathrm{kg}$ wet vegetation when the input was increased by 10\%). However, the maximum CROPRE estimate decreased slightly (from 510 to $500 \mathrm{UOA} / \mathrm{kg}$ ) when the system was not overwatered and increased by a factor of 50 when the system was overwatered. In the CROPRE model, as the CR value increases, more of the radionuclide is incorporated into the organic matter pool becoming unavailable for plant uptake.

Because of the large $\mathrm{K}^{-1}$ value, a large fraction of the ${ }^{99}$ Tc was lost from the system by percolation when the system was overwatered.

The $C R$ value for cesium-135 $\left({ }^{135} \mathrm{Cs}\right)$ was increased from 0.003 to 0.01 in response to data reported by Cataldo et al. (1978). Their CR values for five different arid soil types were converted to a dry soil to wet vegetation basis by assuming that the wet weight of vegetation is larger than the corresponding dry weight by a factor of four. The CR values ranged from 0.0038 to 0.016 for cheatgrass (Bromus tectorum) and from 0.0020 to 0.17 for tumbleweed (Sazsola kazi). When the CR values were increased by a factor of approximately three, the FYAM values were hardly affected because surface deposition contributed more radiocontaminants than root uptake. However, the maximum CROPRE estimates, which were larger in both cases than the FYAM values, were changed almost in proportion to the increase in the CR value.

The neptunium-237 ( $\left.{ }^{237} \mathrm{~Np}\right)$ CR value was increased from 0.0025 to 0.25 , and the americium-243 (243 Am) CR value was increased from 0.00025 to 0.0025 in response to a paper by Schreckhise and Cline (in press). When the CR value 
for ${ }^{237}$ Np was increased by a factor of 100 , the FYAM values were only increased by a factor of 13 because plant surface deposition is the primary source of contamination if the $C R$ values are less than about 0.01 . The maximum CROPRE estimates for ${ }^{237} \mathrm{~Np}$ were increased by a factor of four when the system was not overwatered and by a factor of 20 when it was overwatered. The FYAM estimates were not affected significantly when the CR values were increased by a factor of ten for ${ }^{243} \mathrm{Am}$. However, the maximum CROPRE values were increased by about a factor of six for both watering regimes. 
SUMMARY AND CONCLUSIONS

Previous estimates of the consequences of groundwater intrusion into a geologic isolation repository have shown that the consumption of crop plants irrigated with contaminated water can contribute to human radiation exposure. Certain assumptions must be made to estimate the exposures in situations where the radionuclides are discharged chronically from a geologic repository or some other source over extremely long time periods. Assumptions must be made regarding the extent to which radionuclides accumulate in agricultural soils and the resulting concentrations of contaminants in the edible parts of plants grown in the contaminated soil. Burkholder et a1. (1975) assumed that the concentration of radionuclides in the soil at any given time equaled the total amount deposited on the soil surface during a 50-year period (corrected for physical decay) divided by the soil surface density. They then estimated the concentration of radionuclides in the vegetation by relating the plant to the soil concentration using available concentration ratio values. The contribution from foliar deposition via transfer to edible plant parts was also included in the estimate. However, since some of the radionuclides were predicted to be discharged into the biosphere over millions of years, questions arise concerning the long-term accumulation of radiocontaminants in agriculture soils and the resulting concentrations in vegetation. These questions cannot be answered with the Fifty-Year Accumulation Method (FYAM).

The CROPRE model was developed to predict the long-term accumulation of radiocontaminants in an agricultural system. Of special concern was the accumulation of radionuclides in the soil organic matter. As the organic matter decomposes gradually with time, the incorporated radiocontaminants are released and again become available for root uptake by subsequent generations of plants. To simulate the release of radiocontaminants from the organic matter pool, we modified a model developed by jenkinson and Rayer (1977). Their model simulates the cycling and release of carbon in the Soil Organic Matter Compartment. All radionuclides certainly do not behave identical to carbon; however, the release rate of carbon will probably coincide, regulate, or at least offset the environmental behavior of many radionuclides. The slow 
turnover rates in some of the Soil Organic Matter Compartments strongly affect the build-up of radionuclides in vegetation. The amount of time required for some of the radionuclides to reach maximum equilibrium concentrations exceeded 10,000 years.

The CROPRE model was evaluated for situations in which the crop land was not overwatered as well as for cases where the input rate of irrigation water simulated a 10\% overwatering rate. The results from CROPRE indicate that the FYAM of ten underestimates the concentration of radiocontaminants in edible vegetation for certain situations. Generally, when the system was not overwatered, the estimates from CROPRE exceeded the FYAM values after about 88 years of continual irrigation with contaminated water. However, the maximum CROPRE estimates did not exceed the FYAM values when the concentration ration (CR) value was greater than about five or if the physical half-life of the radionuclide was less than 100 years. As the plant uptake parameter (CR value) was increased, the amount of time required for the CROPRE estimates to reach a maximum value, which usually occurred at times greater than about 1,000 years, decreased. The maximum CROPRE estimates were up to a factor of 120 larger than the corresponding FYAM values. The sorption equilibrium constant $\left(K^{-1}\right)$ had the greatest effect on the concentration of radionuclides in edible vegetation when the system was overwatered. If the value of $K^{-1}$ (ratio of the velocity of the radionuclide to that of water) was larger than about 0.01 , the CROPRE estimates never exceeded the FYAM values. CROPRE estimates for radionuclides that did exceed the FYAM values did so within about 62 years. The maximum CROPRE estimates in those cases were about a factor of 10 larger than the corresponding FYAM estimates.

The CROPRE model simulates realistic processes that occur during the cycling of radiocontaminants in crop plant and soil systems. The simulation of these processes produces much more accurate estimates of the concentrations of radionuclides in edible vegetation than the simple assumption that the radionuclide concentrations are only related to a 50 -year input value without consideration of other important environmental processes. 


\section{RECOMMENDED MODIFICATIONS OF CROPRE}

Incorporation of the CROPRE model into other radiological dose commitment models should improve their ability to accurately predict the radiation doses that would result from ingestion of crop plants that have been irrigated over very long time periods with contaminated water. However, several aspects of CROPRE need to be investigated before it is used to estimate radiation doses to human population from the consumption of contaminated vegetation. The following modifications of the model are required to improve the model's precision and credibility:

(1) The computer program, CROPRE, needs to be modified to lower the amount of computer time required to evaluate the model for long time periods $(t>10,000 \mathrm{yr})$. The program was written initially to evaluate a general deterministic compartmental model. Some of the calculations and manipulations would be modified to reduce the amount of computation time required to complete the evaluation.

(2) Many of the parameters used in the model need to be examined. For instance, the weathering half-time ( 14 days) used to describe the loss rate of the radiocontaminants from the surface of the vegetation may be too small. Wildung et al. (1979) have observed weathering half-times in excess of 150 days for plutonium when it is added to the surface of vegetation in an aqueous suspension, which would be similar to applying radiocontaminants to vegetative surfaces in the irrigation water. The intercept value of the vegetation expressed as a fraction of the total deposited per unit surface area may also be questioned. Both the weathering half-time and the value of the initial vegetative deposition fraction (0.25) were derived from such studies as Martin (1965) and Witherspoon and Taylor (1970) where dry large particles were used. These values may be different if the contaminant is applied through the irrigation water.

(3) The transfer of radionuclides from the surface of the vegetation to the edible plant material (seed in this case) was set at $10 \%$. The observations of wildung et al. (1979) suggest that this value may be incorrect. 
Their observations on the transfer of plutonium and americium from the plant's exterior to the seed, expressed as a fraction of the total deposited on the plant initially, differ from the value used in this model. The mechanisms involved require further study before these transfer rates can be quantified and utilized in the model. This is necessary because, as demonstrated here, foliar deposition can be a very important contributor to the observed levels of certain radionuclides in vegetation.

(4) The concentration ratio values for several of the radionuclides may be incorrect, as indicated where different CR values were used for particular radionuclides. Some CR values were only estimates, while others were determined for different soil types, plant species, or chemical compounds; a 11 affect the credibility of CROPRE.

(5) The root uptake of radionuclides released during the decomposition of the soil organic matter may be different than the uptake rate of the radiocontaminant when it is initialiy incorporated into the plant material. Romney, Mork, and Larson (1970) reported an increase in the concentration of plutonium in clover over a five-year period. This increase suggests that some mechanisms, possibly including biological transformation of.the chemical state of the compound, may increase the phytoavailability of the transuranic element.

(6) The Soil Mineral Compartment was treated as a single compartment even though in actuality is consists of several subcompartments. The model should probably be modified to include these subcompartments in order to describe the mechanisms of chemical compound transfers within the soil matrices and from the soil particles to the roots of the plants. These mechanisms are very important because they govern the rate at which the radiocontaminants move downward through the soil profile, as well as their phytoavailability.

(7) The input rate for the model was constant except for physical decay throughout the entire observation period. However, as Burkholder et a1. (1975) point out, the input rate actually varies with time. The peak discharge rates of the radionuclides from a soil column into the waterway 
vary for each element as a function of its sorption equilibrium constant. For example, for a particular situation the peak discharge rate reported by Burkholder et a1. (1975) for ${ }^{99} \mathrm{Tc}$ occurred from about $t=250 \mathrm{yr}$ to $t=600 \mathrm{yr}$, while the peak for ${ }^{14} \mathrm{C}$ continued for a 400-year period beginning at $t \simeq 1,600 \mathrm{yr}$. The varying input rates for each particular radionuclide should be incorporated into the model. The concentration of a radionuclide in the irrigation water should be decreased to correspond to the end of the peak discharge period for each element. The model would then be evaluated to simulate the level of radiocontaminants in the soil/plant system without any further input in the irrigation water.

(8) Many of the radionuclides found in radioactive waste repositories are products from a decay series, either as a long-lived parent or as shorterlived daughters. Almost all of the daughters within a series have unique chemical characteristics that govern their sorption equilibrium constants and their plant uptake parameters. The model should be modified to consider the decay products associated with each respective parent. This could significantly affect the behavior of many radionuclides. This is especially true for a situation where the system is overwatered and where the decay products have high concentration ratio values and high sorption equilibrium $\left(\mathrm{K}^{-1}\right)$ constants but are daughters of radionuclides that have small sorption equilibrium constants. The resulting concentration of the radionuclide in the vegetation would probably be much higher than if that radionuclide had been applied to the soil initially.

(9) With any model, the questions always remain about its accuracy. The best approach to addressing these questions is usually to validate the model. Experiments are usually designed to verify the predictions from the model. Because of the extremely long time periods involved, it is extremely unrealistic to expect to completely validate this model. However, studies could be conducted to determine the relationships among plant uptake, percolation downward with overwatering, decomposition and re-uptake, and other mechanisms over short time periods to help validate the model, as well as to refine many of the parameters used in the model. 


\section{REFERENCES}

Baker, D. A., G. R. Hoenes, and J. K. Soldat. 1976. "F00D--An Interactive Code to Calculate Internal Radiation Doses from Contaminated Food Products." In Proceedings of the Conference on Environmental Modeling and Simulation, U.S. Environmental Protection Agency, 401 M Street S.W., Washington, DC 20460.

Booth, R. S., S. V. Kaye, and P. S. Rohwer. 1971. "A Systems Analysis Methodology for Predicting Dose to Man from a Radioactivity Contaminated Terrestial Environment." In Proceedings of the Third National Symposium on Radioecology, ed. D. J. Nelson. USAEC CONF-710501, Pt 2, NTIS, Springfield, $V A$.

Burkholder, H. C., M. 0. Cloninger, D. A. Baker, and G. Jansen. 1975. Incentives for Partitioning High-Level Waste. BNWL-1727, Pacific Northwest Laboratory, Richland, WA 99352.

Cataldo, D. A., R. C. Routson, D. Paine, and T. R. Garland. 1978. Relationships Between Properties of Hanford Area Soils and the Availability of $134 \mathrm{Cs}$ and ${ }^{85} \mathrm{Sr}$ for Uptake by Cheatgrass and Tumbleweed. PNL-2496, Pacific Northwest Laboratory, Richland, WA 99352.

Cline, J.F., and F. P. Hungate. 1956. "Effect of Strontium and Calcium in So $i 1$ on Uptake of ${ }^{90} \mathrm{Sr}$ by Barley Plants." In Biology Research--Annual Report 1955. (pp 7-13). HW-41500, Hanford Atomic Products Operation, Richland, WA 99352.

Energy Research and Development Administration. 1975. Final Environmental Statement, Waste Management Operations. USERDA-1538, Hanford Reservation, Richland, WA 99352.

Jenkinson, D. S., and J. H. Rayner. 1977. "The Turnover of Soil Organic Matter in Some of the Rothamsted Classical Experiments." Soil Science, $123(5): 298-305$.

Martin, W. E. 1965. "Interception and Retention of Fallout by Desert Shrubs." Hea 1th Physics 11:1341-1354.

Ng, Y.C., C. A. Burton, S. E. Thompson, R. K. Tandy, H. K. Kretner, and M. W. Platt. 1968. Prediction of the Maximum Dose to Man from the FallOut of Nuclear Devices. Part IV of Handbook for Estimating the Maximum Internal Dose from Radionuclides Released to the Biosphere. UCRL-50163 PT IV, Lawrence Radiation Laboratory, University of California, Livermore, CA.

Rediske, J.H. and A. A. Selders. 1953. "The Absorption and Translocation of Strontium by Plants." Plant Physiology. 28:594. 
Romney, E. M., H. M. Mork, and K. H. Larson. 1970. "Persistence of Plutonium in Soil, Plants and Small Mamma 1s." Health Physics 19(4):487-492.

Routson, R. C., and D. A. Cataldo. 1977. Tumbleweed and Cheatgrass Uptake of ${ }^{99} \mathrm{Tc}$ from Five Hanford Soils. BNWL-2183, Pacific Northwest Laboratory, Richland, WA 99352.

Routson, R. C., and D. A. Cataldo. 1978. "A Growth Chamber Study of the Effect of Soil Concentration and Plant Age on the Uptake of Sr and Cs by Tumbleweed." Soil Science and Plant Analysis 9(3):215-229.

Scarborough, J. B. 1965. Differential Equations and Applications. Waverly Press, Inc., Baltimore, $\overline{M D}$.

Schreckhise, R. G. and J. F. Cline. (in press). "Comparative Uptake and Distribution of Plutonium, Americium, Curium, and Neptunium in Four Plant Species." In Transuranic Elements in the Environment, ed. W. C. Hanson. TID-22800. U.S. Department of Energy, Washington, DC.

Soldat, J. K. 1971. Modeling of Environmental Pathways and Radiation Doses from Nuclear Facilities. BNWL-SA-3939, Pacific Northwest Laboratory, Richland, WA 99352.

Wildung, R. E., D. A. Cataldo, and T. R. Garland. 1976. "Accumulation of Technitium by Plants." Health Physics 32(4):315-317.

Wildung, R. E., T. R. Garland, K. M. McFadden, J. E. Rogers, D. A. Cataldo, and M. F. Sullivan. 1979. "Transuranic Behavior in Soils and Plants." In Pacific Northwest Laboratory Annual Report for 1978, Part 2, Ecological Sciences. PNL-2850, Pacific Northwest Laboratory, Richland, WA 99352. 
APPENDIX A 
PROGRAM CROPKE (INPUT, OUTPUT. TAPES=INPUT, TAPEO=OUTPUT)

PROGRAM CRUPRE WAS WRITTEN GY R. GENE SCHRECKHISE (1978) TO NUMEHICALLY EVALUATE THE UETERMINISTIC MODEL ENTITLED CROPRE. THE MODEL IS DUCUMENTEU IN PNL-2636 ISIMULATION OF THE LONG-TERM ACCUMULATION OF RAOIUCONTAMINANTS IN CROP PLANTS GY

R. G. SCHRECKHISE, IУ४OI

THE MOOEL IS NUMERICALLY EVALUATED USING THE EULER TECHIVIUUE TO APPROXIMATE THE SOLUTION OF THE OIFFEKENTIAL EQUATIONS THAT DESCRIBE THE TRANSFER OF MATERIAL BETWEEN COMPARTMENTS. TIME IS THE ORIVING FUNCTION. TRANSFER COEFFICIENTS. FK(I,J), DESCRIBE THE FRACTIONAL IRANSFER OF THE MATERIAL IN COMPARTMENT J TO CUMPARTMENT I PER UNIT TIME. THE QUANITY OF MATERIAL IN COMPARTMENT J OR I IS EXPRESSEU AS Q(J) OR U(I).

If FK(JJ) EQUALS THE NEGATIVE SUM OF ALL THE EXISTING THANSFER COEFF ICIENTS THAT LEAO INTO COMPARTMENT I, THEN THE GENERAL FORM OF THE OIFFERENTIAL EOUATION UESLFIBING THE INSTANTEOUS RATE OF CHANGE IN COMPARTMENT I IS EUUAL TO THE SUM OF FK(I,J) TIMES O(J), WHERE J EQUALS I TU 10 (TOTAL NUMBER OF COMPARTMENTS). THE VALUE OF Q(I) AT TIME T PLUS UELTA T EQUALS O(I) AT TIME T PLUS DELTA T TIMES THE DIFFERENTIAL EQUATION FOR COMPARTMENT J.

the Value of delta $T$ must be set at a Value so that the prouuct of ANY OF THE FK(I.J) VALUES TIMES DELTA T DOES NUT EXEEU 1.0. DELTA T IS NORMALLY SET AT 0.05 YK. TMIS RESULTS IN A LARUE AMOUNT OF COMPUTER TIME NECESSARY TO EVALUATE THIS MOUEL FOR LONG TIME PERIOUS. THIS PROGRAM TOOK APPROXIMATELY 8 SECONOS OF COMPUTER TIME ON HANFORD'S CDC CYBER 7600 PER 1000 YR TIME PERIOD.

THE DATA CAROS ARE AS FOLLOWS--

COL. VAR. FOR. DESCRIPTION - - CARU I- - CARU I- - CARD - isotr alo radionuclioe to be evaluated.

$1-10$ ISOT 1

11-20 T2 G10.j PHYSICAL HALF-LIFE (YEARS), IF UNKNOWN, OMIT. $21-30$ TI GI0.3 PHYSICAL HALF-LIFE (YEARS) OF INPUT, IF CONSTANT LEAVE BLANK.

31-40 CR GIO.3 CONCENTRATION RATIO (WET VEGETATION TO DRY SOIL).

41-50 AKI GI0.3 SORPTION EUUILIBKIUM CONSTANT.

S1-55 PERC FS.0 OVER-WATER PERCENTAGE.

50-60 DT F5.0 DELTA TIME (YEARS).

01-05 TZ F5.0 TIME ZERO VALUE.

66-75 TMAX GI0.3 MAXIMUM TIME TO BE EVALUATED.

70-80 NPK IS NUMBER OF INCREMENTS TO BE PRINTED, EXCLUDING INITIAL TIME VALUES. 


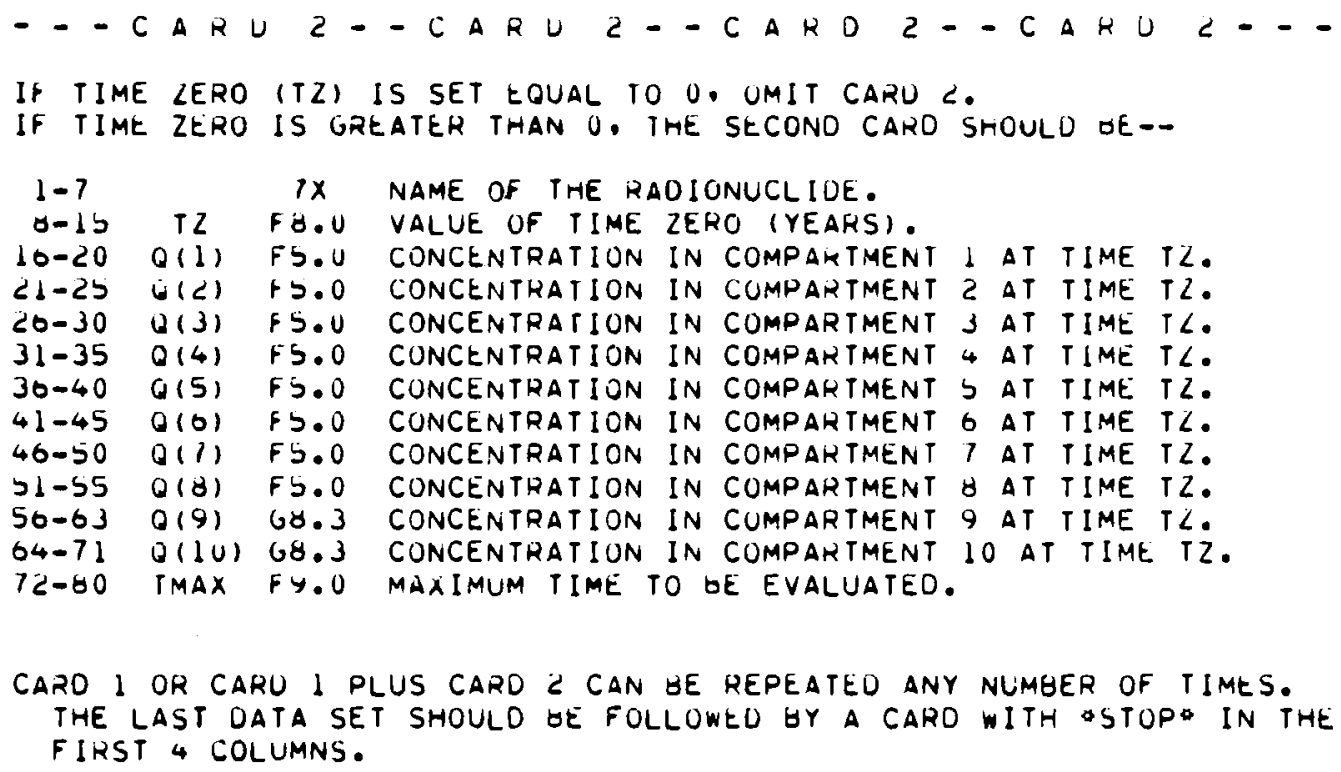

CARO I OR CARU I PLUS CARD 2 CAN BE REPEATED aNY NUMBER OF TIMES. THE LAST OATA SET SHOULD GE FOLLOWED GY A CARD WITH OSTOP IN THE FIRST 4 COLUMNS.

DIMENSION IT $(10), Q(10), F F(10,10), Y O B S(10), G(10), J K(10)$ COMMON/LI/NC COMMON/LJ/V $(10), F K(10,10)$

IT(I)"S ARE THE COMPAFTMENT TITLES, I INAPUT IIRRIGATION, IS KEPT CONSTANT EXCEPT FOR PHYSICAL DECAY, $z=V E G E T A I I V E$ SURFACE. $3=V E G E T A T I V E$ TISSUE, $4=$ DECOMPOSAULE PLANT MATERIAL, J=RESISTANT PLANT MATERIAL, G=UIOMASS, $7=$ PHYSICALLY STAUILIZED ORGANIC MATTER, O=CHEMICALLY STAEILIZED OKGANIC MATTER, 9=SOIL MINERAL COMPARTMENT, AND $10=S I N K$.

DATA (ITI),I I I.1U)/IOMINPUT,IRR. . IOH VEG SUR, , IOHVEG TISSUE. $110 H$ UPM-SOM, IUN RPM-SUM, IOH BIO-SOM, IOH POM-SOM, $210 H$ COM-SOM, IOHSOIL MIN. IOH SINK,

THe fF(I.J) values are the InItIal transfer coefficients in fraction PER YEAR.

UATA $(F F(1, J), J=1,1 \cup) /-1, .900 .1$

DATA (FF $(<, J), J=1,10), .25,-1,0,8 \$ 0.1$

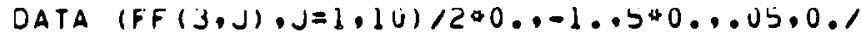

UATA (FF $(4, J), J=1,10) 10,0.753,0.67,-4.1797,6 \$ 0.1$

DATA (FF(J,J),J=1,10),0...147,.1j,0..-.30045,500.1

DATA (FF (0,J),J=1,10)/300...319,.00220,..37853..00106,.0000260,

$12 * 0.1$

UATA (FF (7,J),J=1.10),300...525,.0375,.0511,-.11<119,.0040438, $12 \$ 0.1$

OATA (FF $(8, J), J=1,10) / 300 ., .0147, .00105, .00143, .0000490,-.0000348$, 1200.1

DATA (FF $(9, J), J=1,10) / .75,18.071,0, .3 .34, .239, .326, .0111, .000278$. $1-.471,0.1$

DATA (FF $(10, J), J=1,10) / 0 \ldots, 1, .2,500,1.421,0.1$

UATA $(J K(I), I=1,10) / 1 H 1,1 H 2,1 H 3,1 H 4,1 H 5,1 H 6,1 H 7,1 H 8,1 H 9,1 H O /$ 


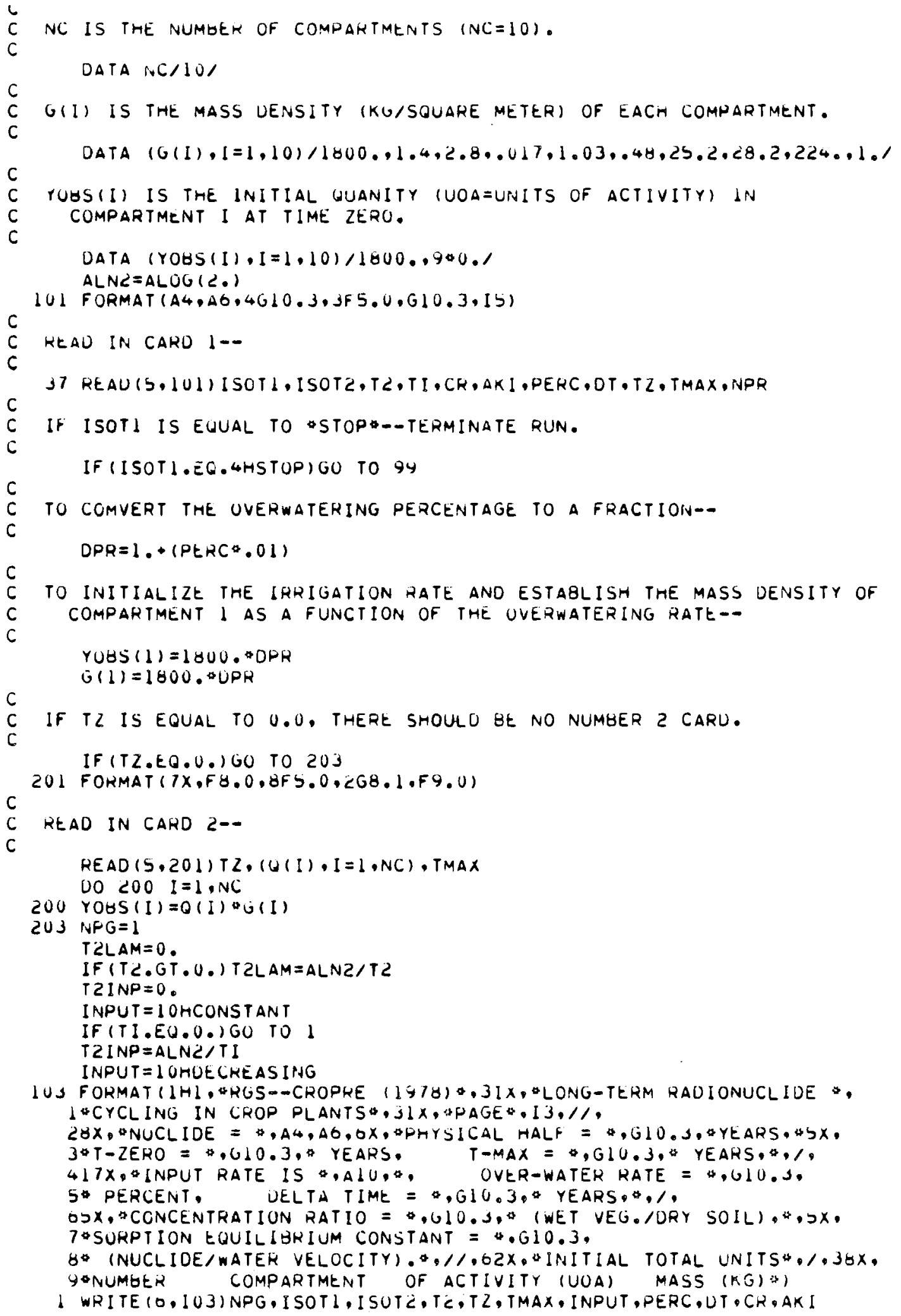


C TO CONVERT TO CONCENTEATION ANO INITIALIZE VII)--

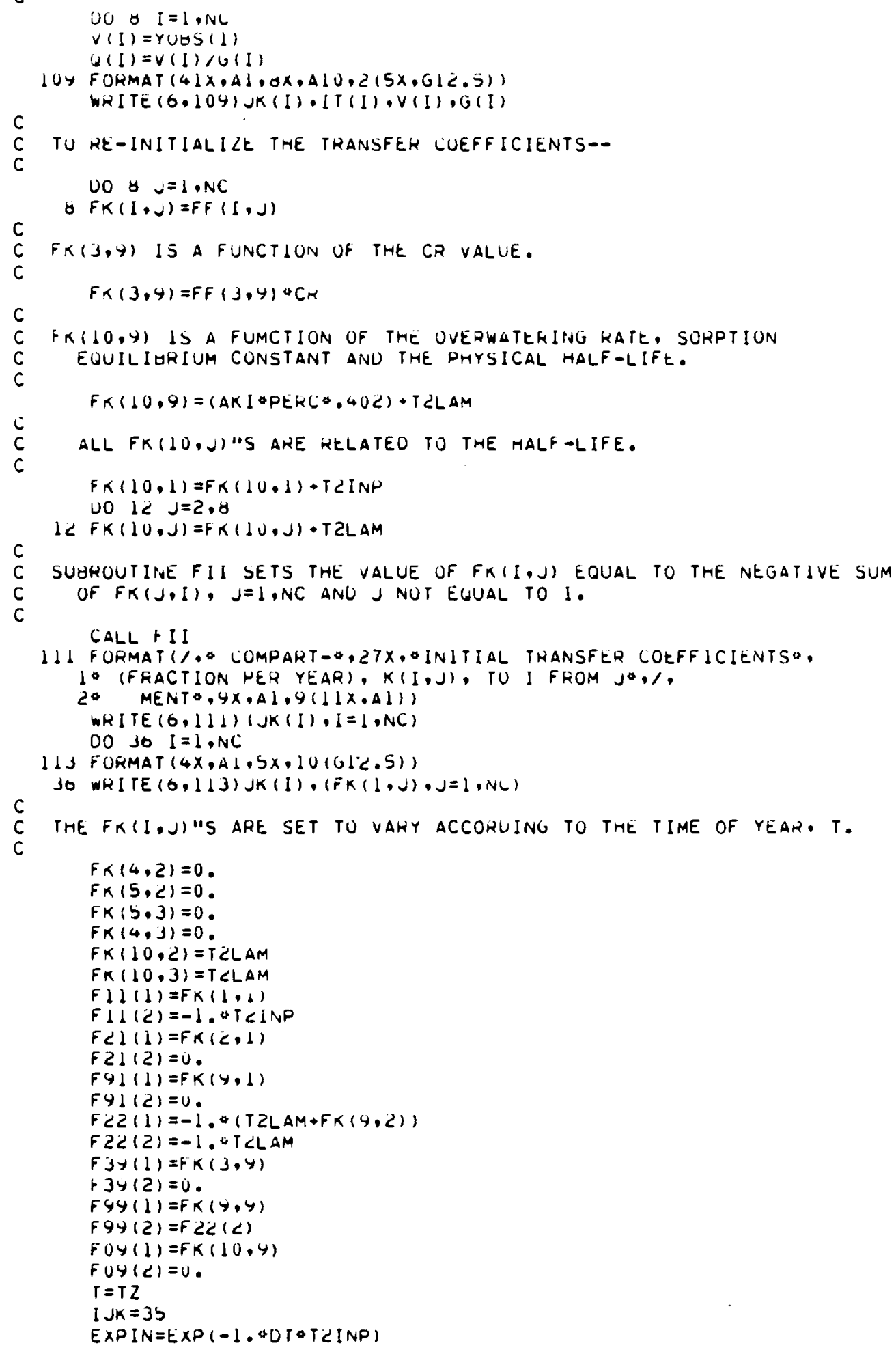




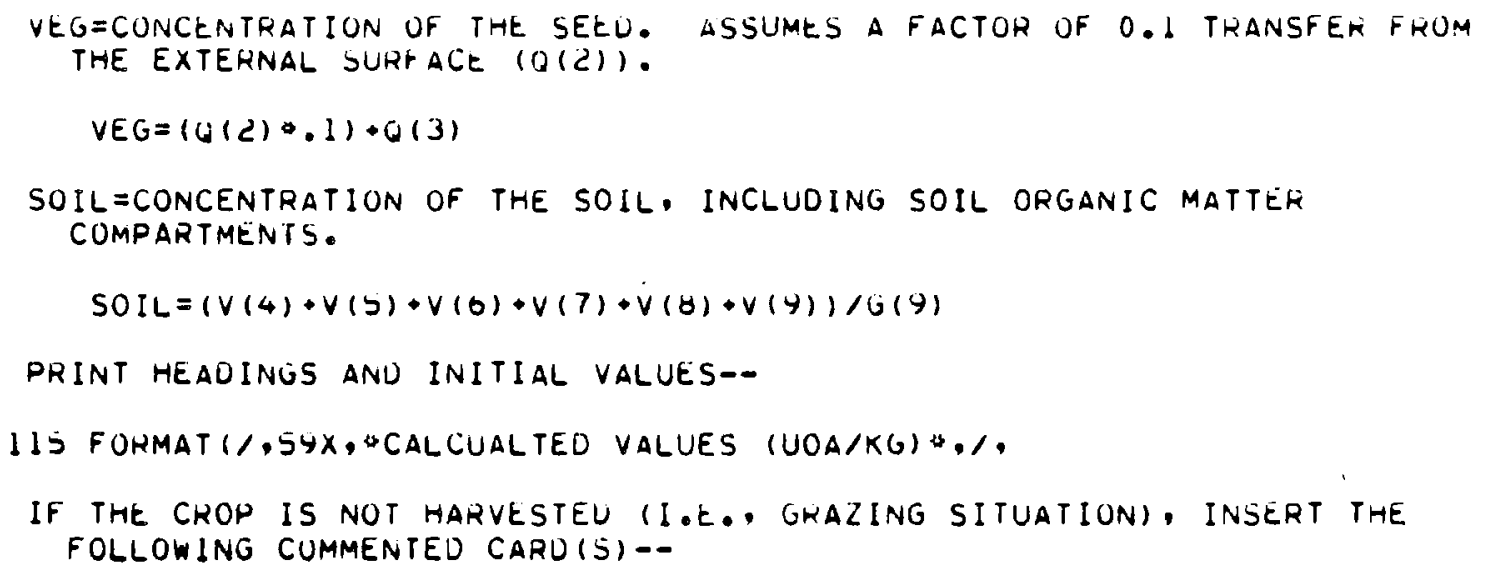




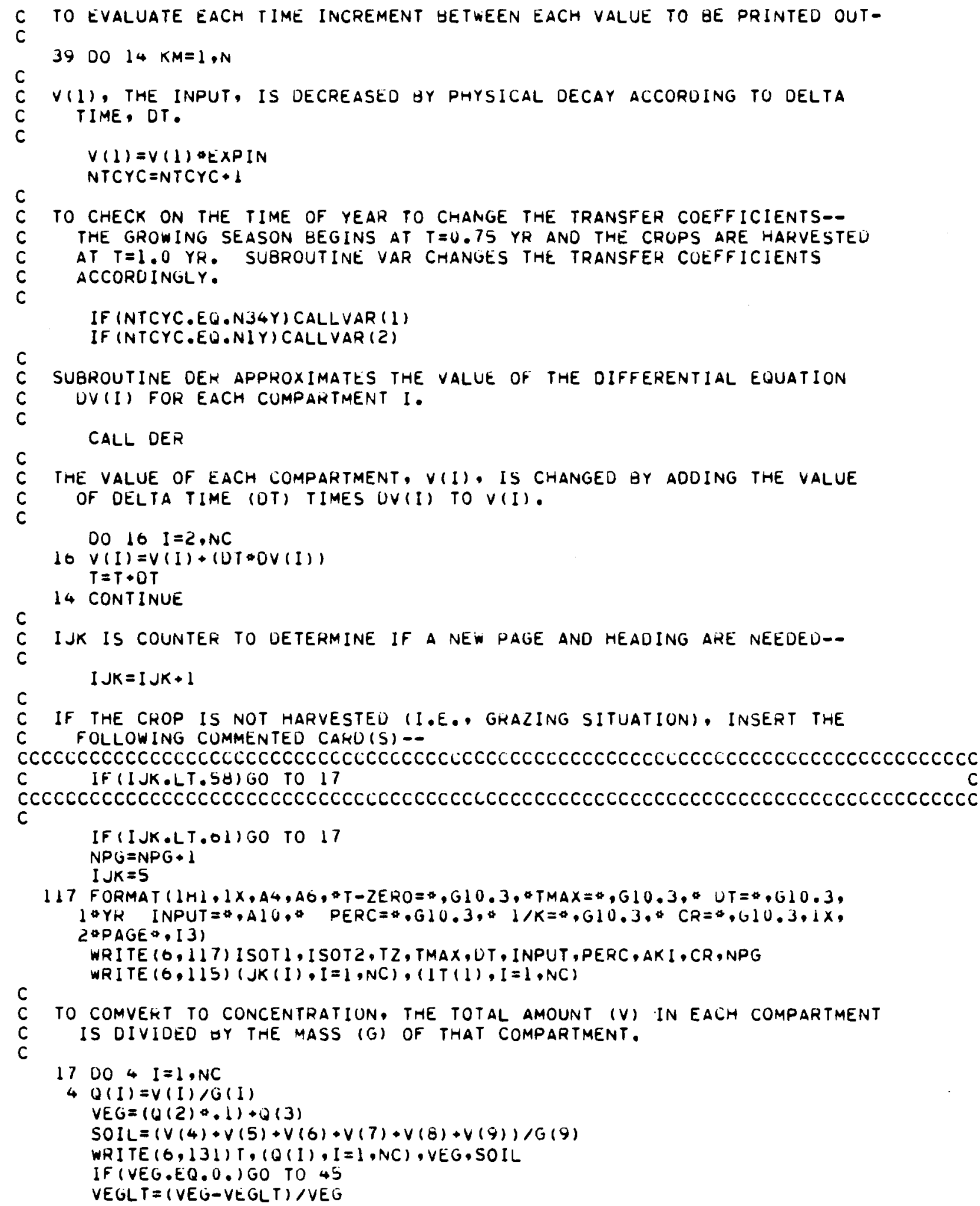




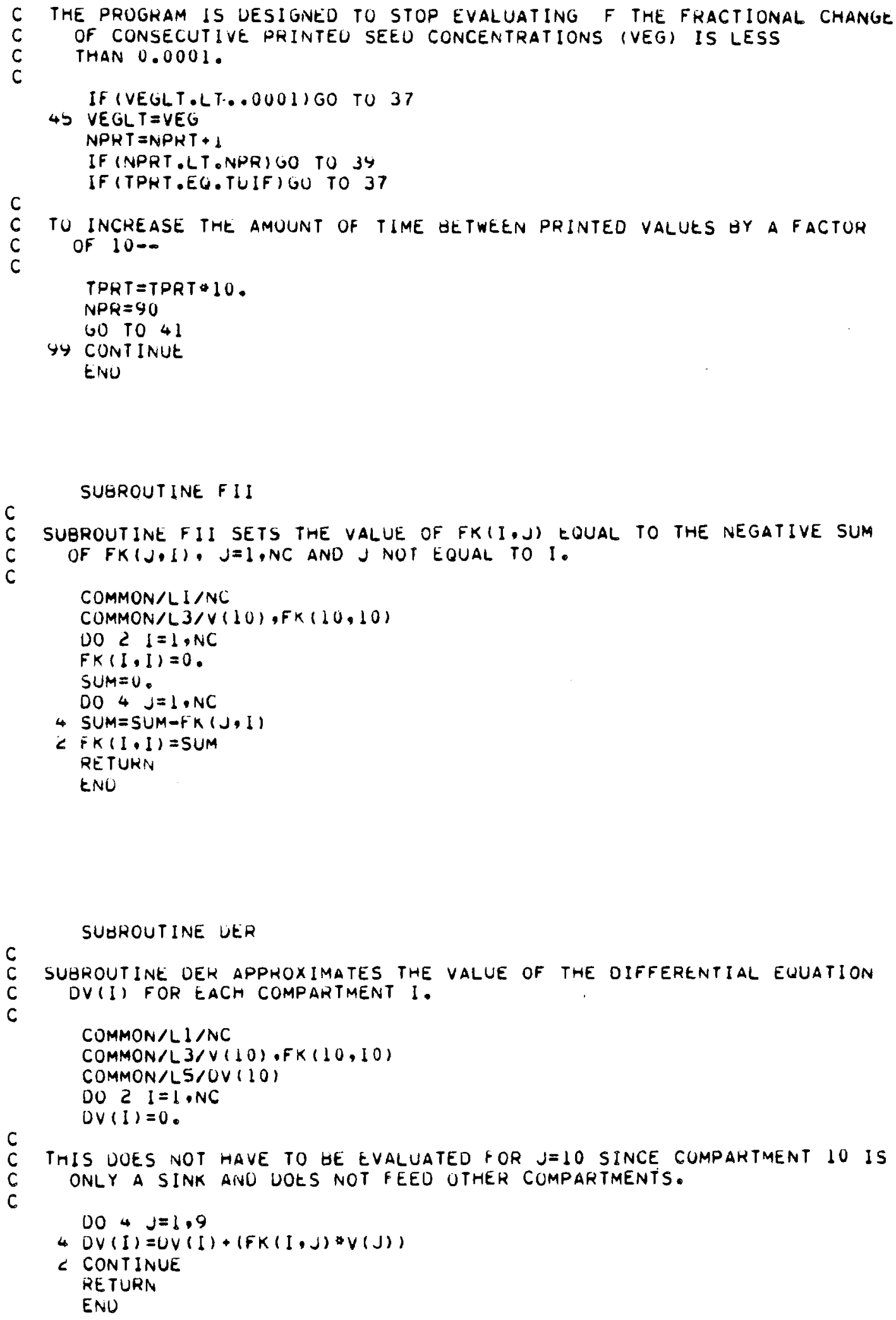




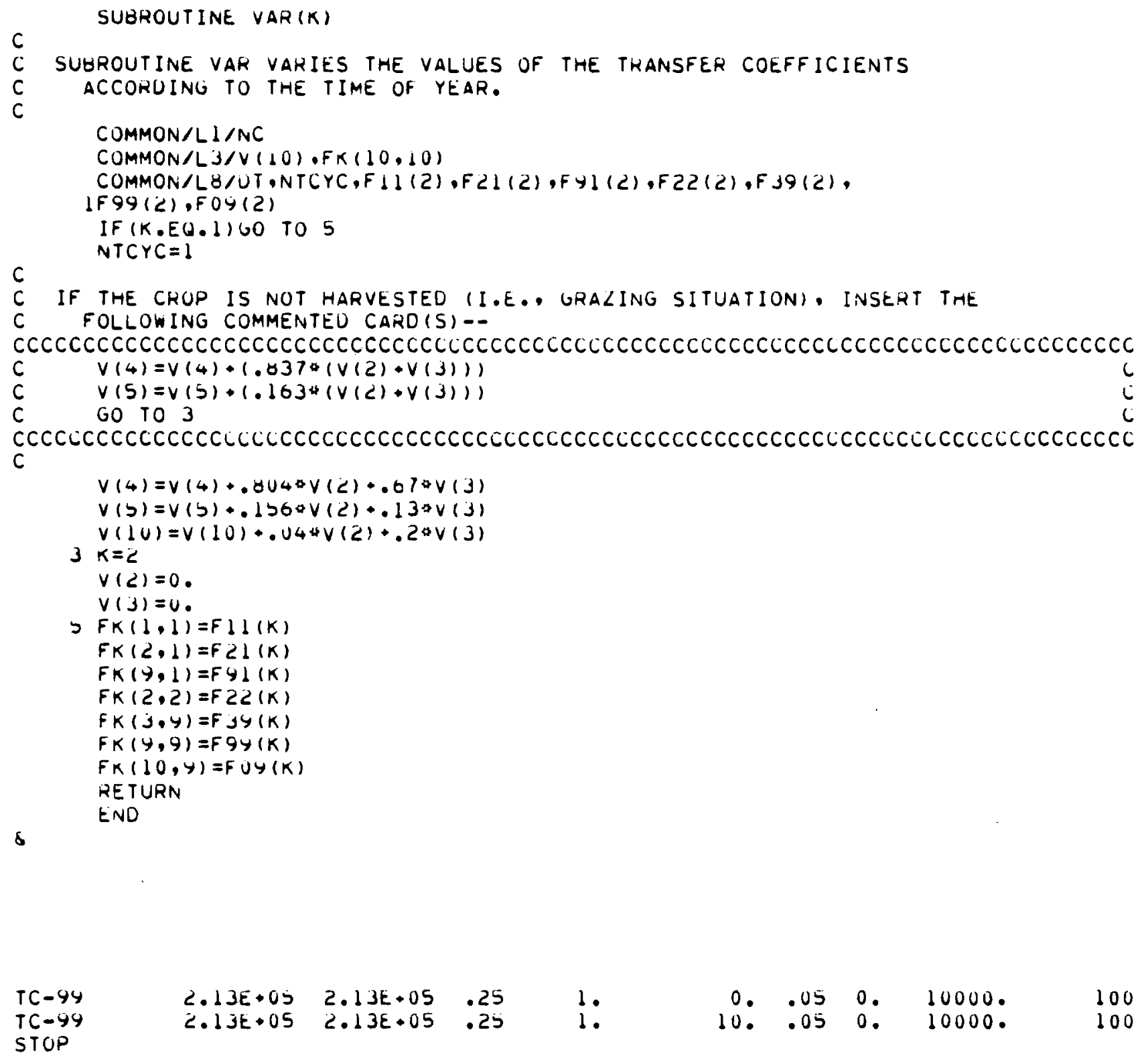


RGS--CHOPHE $(1978)$

LONG-TERM RADIONUCLIUE CYCLING IN ChUP PLANTS

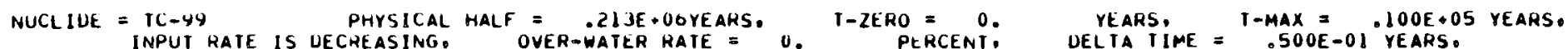

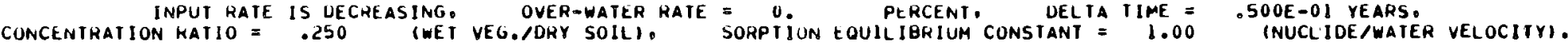

\begin{tabular}{|c|c|c|c|}
\hline NUMBER & & $\begin{array}{l}\text { INITIAL TOTAL UNITS } \\
\text { OF ACTIVITY IUOAI }\end{array}$ & MASS $(K G)$ \\
\hline 1 & INPUT IRR。 & 1000.0 & 1000.0 \\
\hline 2 & VEG SUR. & 0. & 1.4000 \\
\hline 3 & VEG TISSUE & u. & 2.0000 \\
\hline 4 & DPM-SOM & u. & $.17000 E$ \\
\hline ל & HPM-SOM & u. & 1.0000 \\
\hline 0 & $\mathrm{BIO}-50 \mathrm{M}$ & 0 . & .48000 \\
\hline 7 & POM-SOM & 0. & 25.200 \\
\hline$\theta$ & COM-SOM & 0。 & 28.200 \\
\hline$q$ & SOIL MIN. & 0. & $22^{4} .00$ \\
\hline 0 & SINK & u. & 1.0000 \\
\hline
\end{tabular}

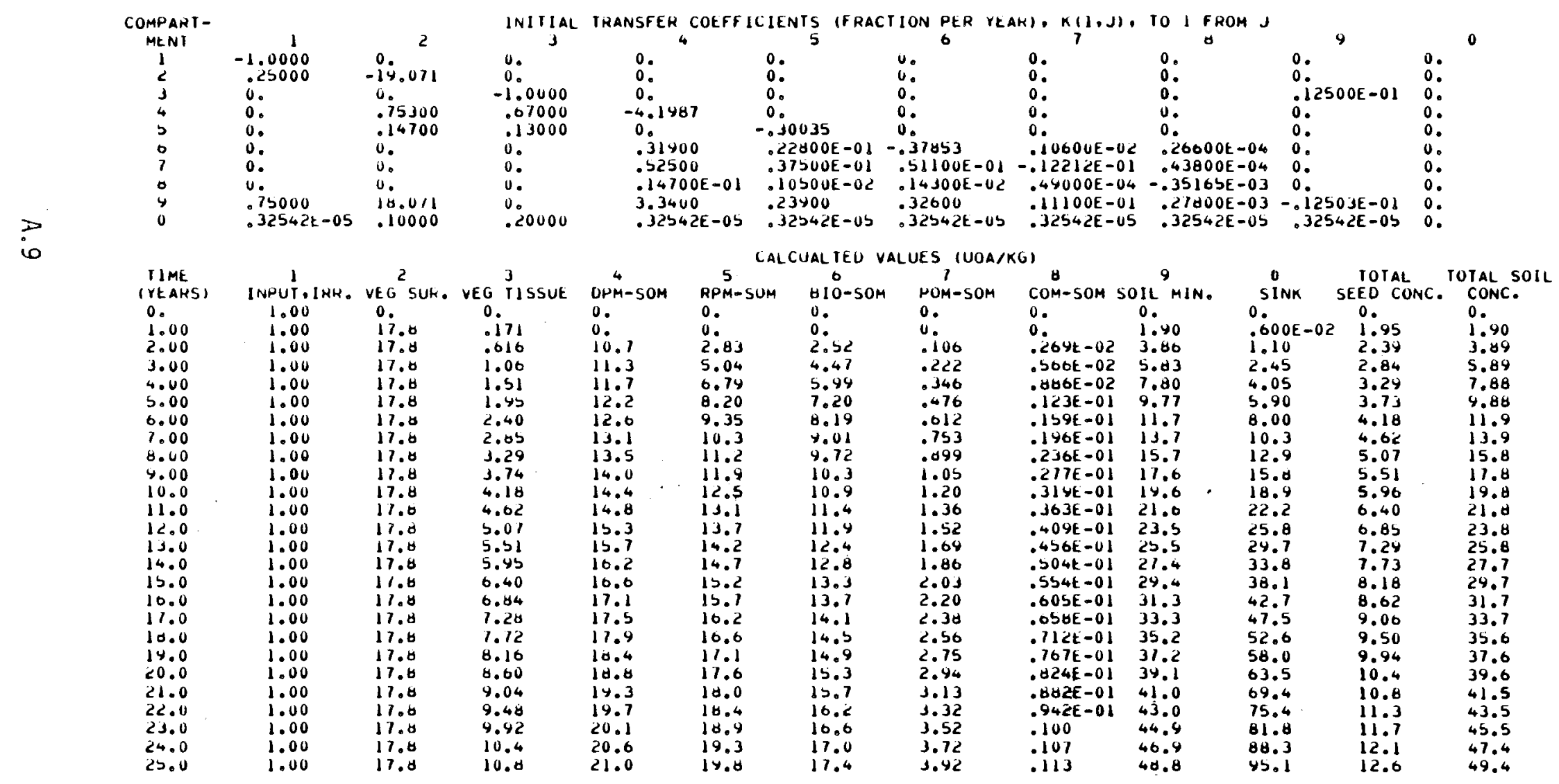




\begin{tabular}{|c|c|c|c|c|c|c|c|c|c|c|c|c|}
\hline IC -49 & $T-\angle E R O=U$ & TMA & $.100 E+0$ & $5 \mathrm{DT}=$ & $O E-0 I Y K$ & $I N P U T=O E C H$ & AS ING & $c=0$. & $1 / K=$ & 1.00 & .250 & PAGE \\
\hline $\begin{array}{l}\text { TIME } \\
\text { TYEAHS } \\
20.0 \\
27.0 \\
20.0 \\
24.0 \\
30.0 \\
31.0 \\
32.0 \\
33.0 \\
34.0 \\
33.0 \\
30.0 \\
37.0 \\
30.0 \\
34.0 \\
40.0 \\
41.0 \\
42.0 \\
43.0 \\
44.0 \\
45.0 \\
40.0 \\
41.0 \\
40.0 \\
49.0 \\
30.0 \\
51.0 \\
52.0 \\
33.0\end{array}$ & 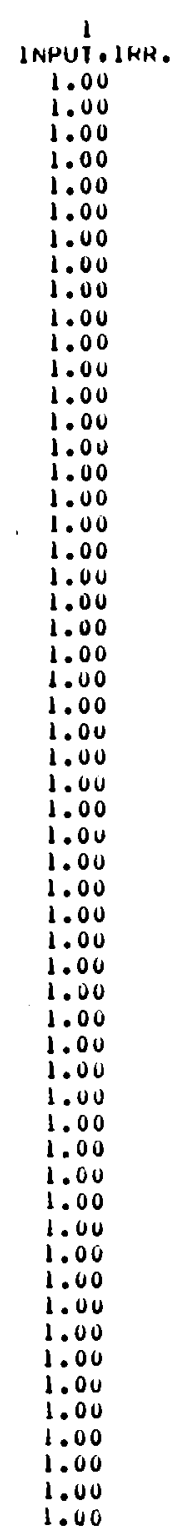 & 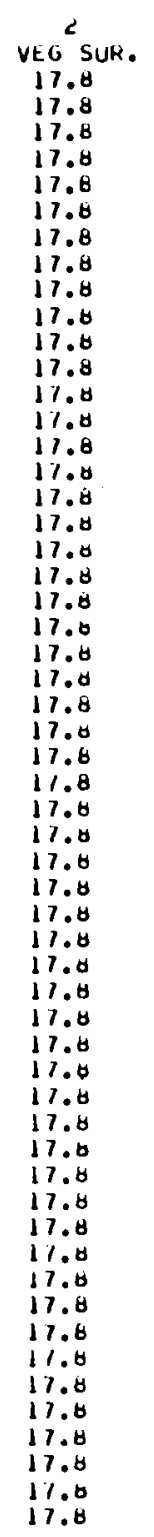 & 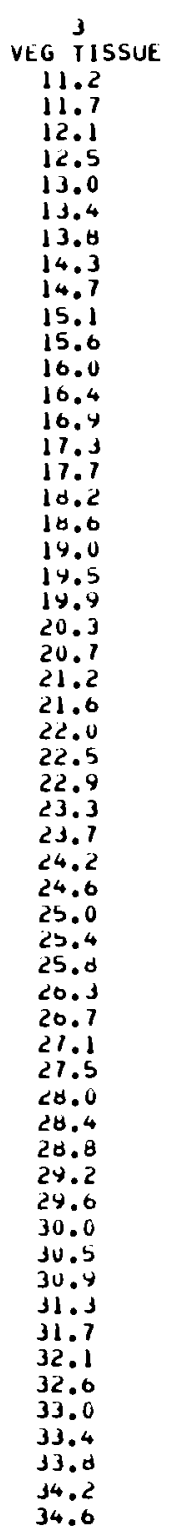 & 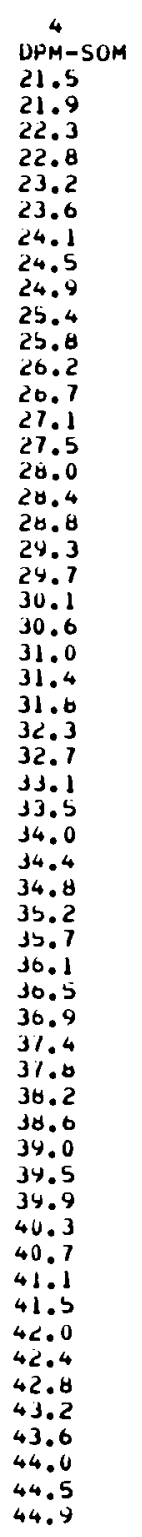 & 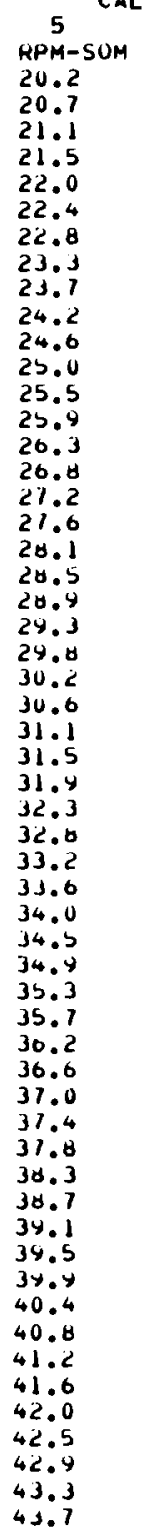 & 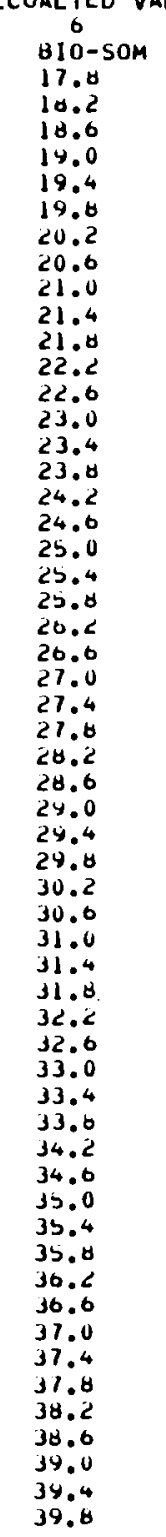 & 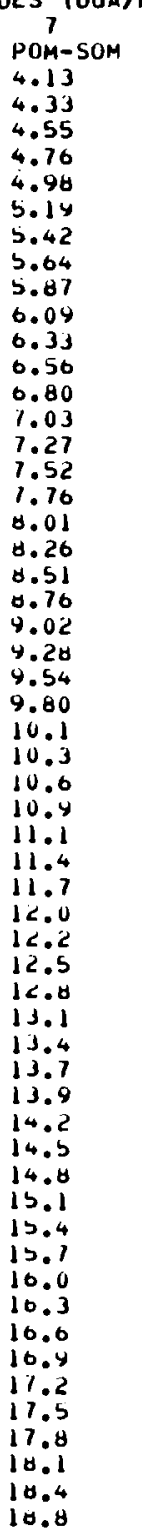 & 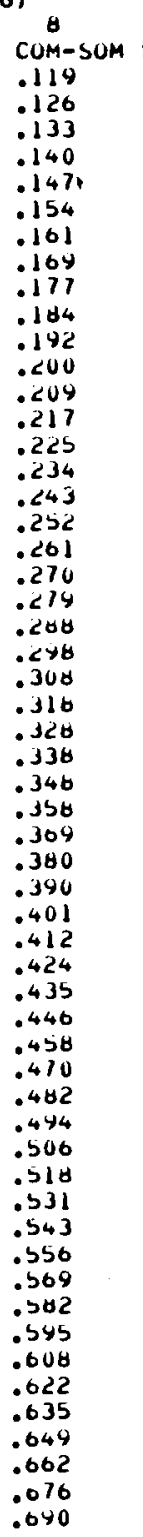 & 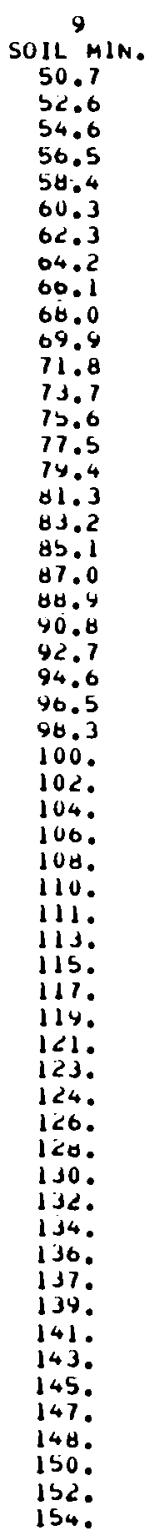 & 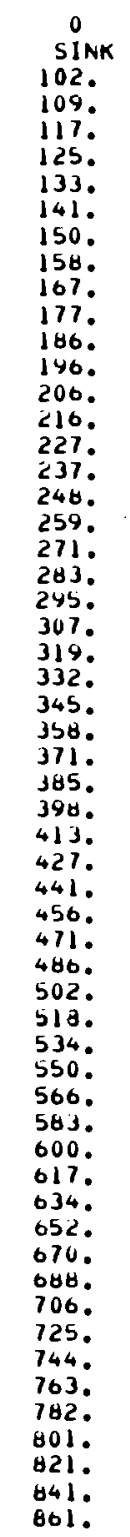 & 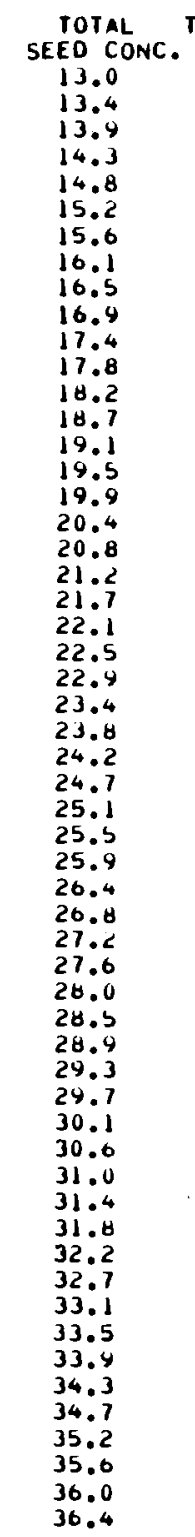 & $\begin{array}{l}\text { TOTAL SOIL } \\
\text { CONC. } \\
\text { S1.3 } \\
53.3 \\
55.2 \\
57.2 \\
59.1 \\
61.1 \\
63.0 \\
65.0 \\
66.9 \\
68.9 \\
70.8 \\
72.7 \\
14.7 \\
70.6 \\
78.6 \\
80.5 \\
82.4 \\
84.3 \\
86.3 \\
88.2 \\
90.1 \\
92.0 \\
94.0 \\
95.9 \\
97.8 \\
99.7 \\
102 . \\
104 . \\
105 . \\
1107 . \\
109 . \\
111 . \\
113 . \\
115 . \\
117 . \\
119 . \\
121 . \\
123 . \\
124 . \\
126 . \\
128 . \\
130 . \\
132 . \\
1340 \\
136 . \\
138 . \\
140 . \\
141 . \\
143 . \\
145 . \\
147 . \\
149 . \\
151 . \\
153 . \\
155 . \\
156 .\end{array}$ \\
\hline
\end{tabular}




\begin{tabular}{|c|c|c|c|c|c|c|c|c|c|c|c|c|}
\hline TC-yg & $T-Z E R O=0$ & IMA & $A X=.100 E \cdot 05$ & $5 \mathrm{DT}=$. & $.500 E-01 Y R$ & INPUT $=\mathrm{OECR}$ & ASING & $c=0$. & $1 / K=$ & 1.00 & .250 & PAGE \\
\hline 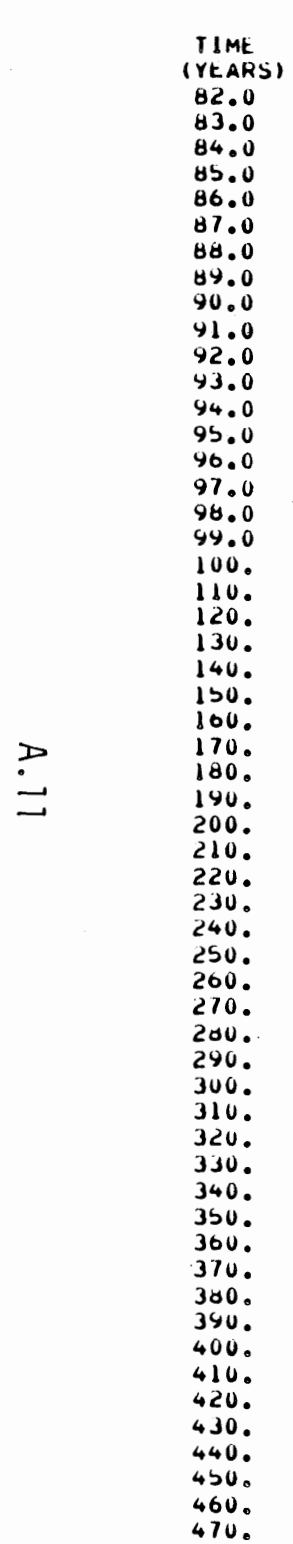 & 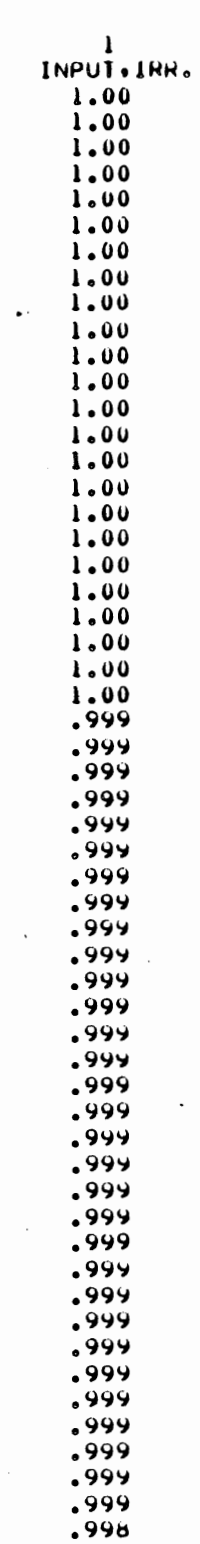 & $\begin{array}{l}\text { Pto } \\
\text { Y7.8 } \\
17.8 \\
17.8 \\
17.8 \\
17.8 \\
17.8 \\
17.8 \\
17.8 \\
17.8 \\
17.8 \\
17.8 \\
17.8 \\
17.8 \\
17.8 \\
17.8 \\
17.8 \\
17.8 \\
17.8 \\
17.8 \\
17.8 \\
17.8 \\
17.8 \\
17.8 \\
17.8 \\
17.8 \\
17.8 \\
17.8 \\
17.8 \\
17.8 \\
17.8 \\
17.8 \\
17.8\end{array}$ & $\begin{array}{l}3 \\
\text { VEG TISSUt } \\
35.0 \\
35.5 \\
35.9 \\
36.3 \\
36.7 \\
37.1 \\
37.5 \\
37.4 \\
30.3 \\
38.7 \\
39.2 \\
39.6 \\
40.0 \\
40.4 \\
40.4 \\
41.2 \\
41.0 \\
42.0 \\
42.4 \\
40.5 \\
50.5 \\
54.5 \\
58.4 \\
62.3 \\
66.2 \\
70.0 \\
73.8 \\
77.0 \\
81.3 \\
85.0 \\
48.7 \\
92.3 \\
95.9 \\
94.5 \\
103 . \\
107 . \\
110 . \\
113 . \\
117 . \\
120 . \\
124 . \\
127 . \\
130 . \\
134 . \\
137 . \\
140 . \\
1430 \\
146 . \\
130 . \\
153 . \\
156 . \\
159 . \\
162 . \\
165 . \\
160 . \\
171 . \\
\end{array}$ & 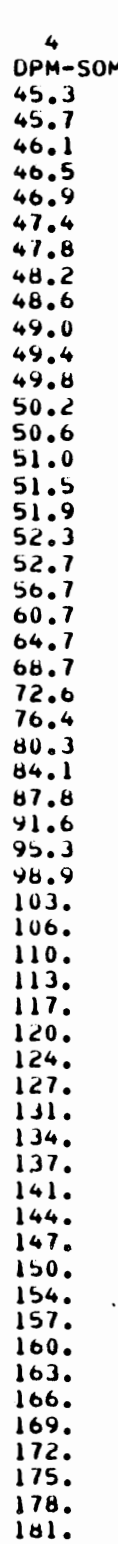 & 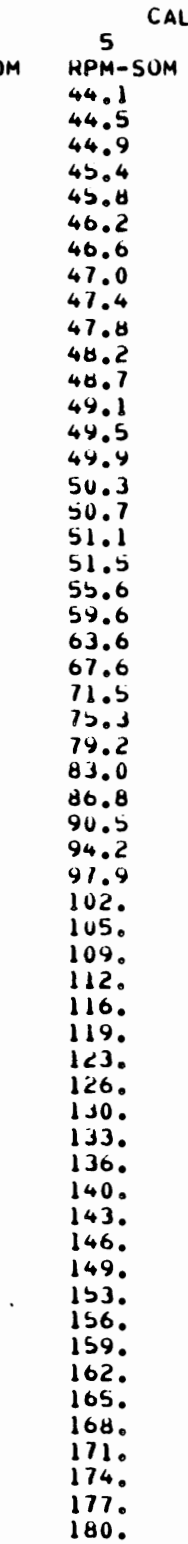 & $\begin{array}{l}\text { CUALIEO VA } \\
6 \\
810-5 O M \\
40.2 \\
40.6 \\
41.0 \\
41.4 \\
41.8 \\
42.2 \\
42.6 \\
43.0 \\
43.4 \\
43.8 \\
44.2 \\
44.0 \\
45.0 \\
45.4 \\
45.0 \\
46.2 \\
46.6 \\
47.0 \\
47.4 \\
51.3 \\
55.2 \\
59.1 \\
63.0 \\
66.8 \\
70.7 \\
74.5 \\
78.2 \\
82.0 \\
85.7 \\
84.4 \\
93.1 \\
96.7 \\
100 . \\
104 . \\
107 . \\
111 . \\
114 . \\
118 . \\
121 . \\
125 . \\
128 . \\
132 . \\
135 . \\
138 . \\
141 . \\
145 . \\
140 . \\
151 . \\
154 . \\
157 . \\
161 . \\
164 . \\
167 . \\
170 . \\
173 . \\
176 . \\
\end{array}$ & 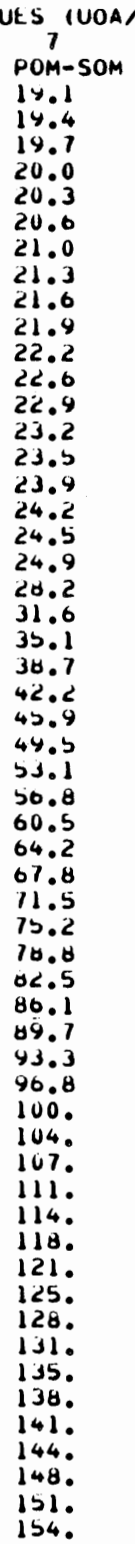 & 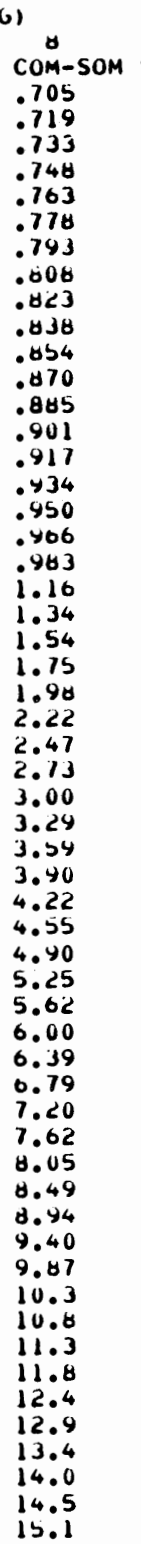 & 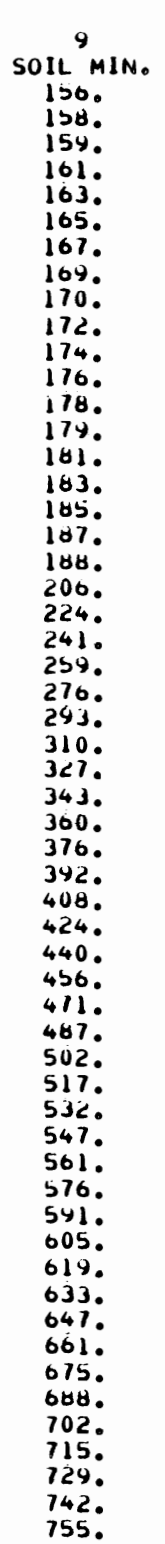 & $\begin{array}{l}0 \\
\text { SINK } \\
882 . \\
902 . \\
923 . \\
944 \\
966 . \\
987 . \\
.101 E+04 \\
.103 E+04 \\
.105 E+04 \\
.108 E+04 \\
.110 E+04 \\
.112 E+04 \\
.114 E+04 \\
.117 E+04 \\
.119 E+04 \\
.122 E+04 \\
.124 E+04 \\
.120 E+04 \\
.129 E+04 \\
.155 E+04 \\
.183 E+04 \\
.213 E+04 \\
.246 E+04 \\
.280 E+04 \\
.317 E+04 \\
.356 E+04 \\
.398 E+04 \\
.441 E+04 \\
.486 E+04 \\
.534 E+04 \\
.584 E+04 \\
.635 E+04 \\
.689 E+04 \\
.74 b E+04 \\
.802 E+04 \\
.862 E+04 \\
.924 E+04 \\
.987 E+04 \\
.105 E+05 \\
.112 E+05 \\
.119 E+05 \\
.126 E+05 \\
.133 E+05 \\
.141 E+05 \\
.149 E+05 \\
.156 E+05 \\
.164 E+05 \\
.173 E+05 \\
.181 E+05 \\
.190 E+05 \\
.198 E+05 \\
.207 E+05 \\
.216 E+05 \\
.226 E+05 \\
.235 E+05 \\
.245 E+05 \\
\end{array}$ & 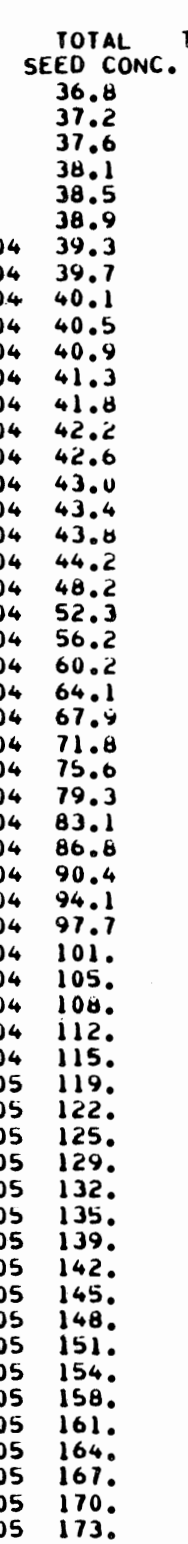 & 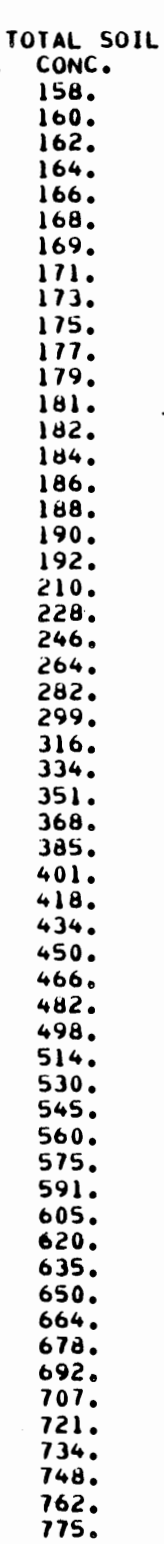 \\
\hline
\end{tabular}




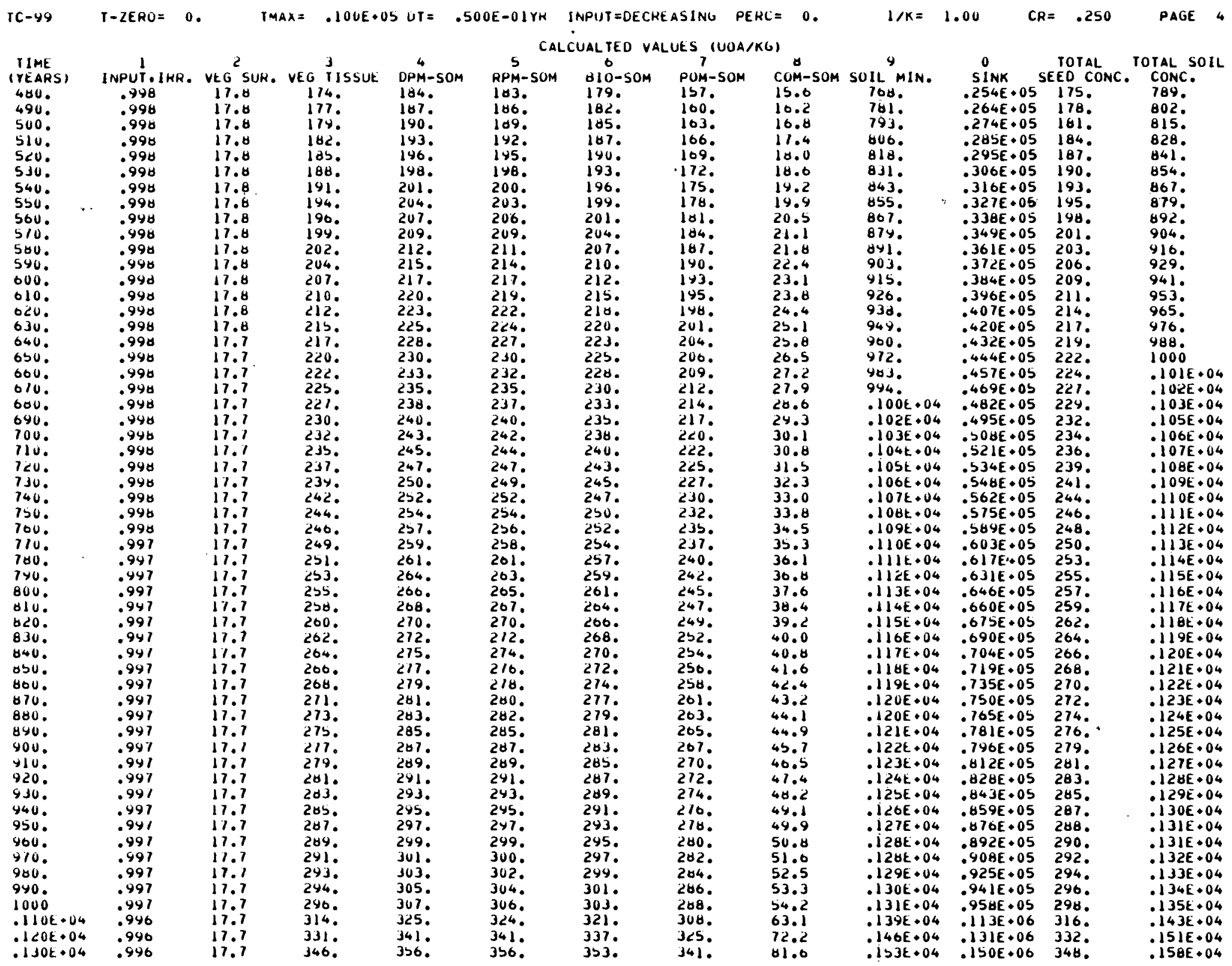




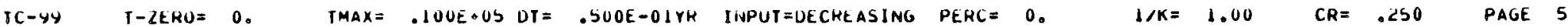
TIME 1 INPUT,IKR. VEG SUR. VEG IISSUE UPM-SOM 5 CALCUALTED VALUES (UOA/KG)

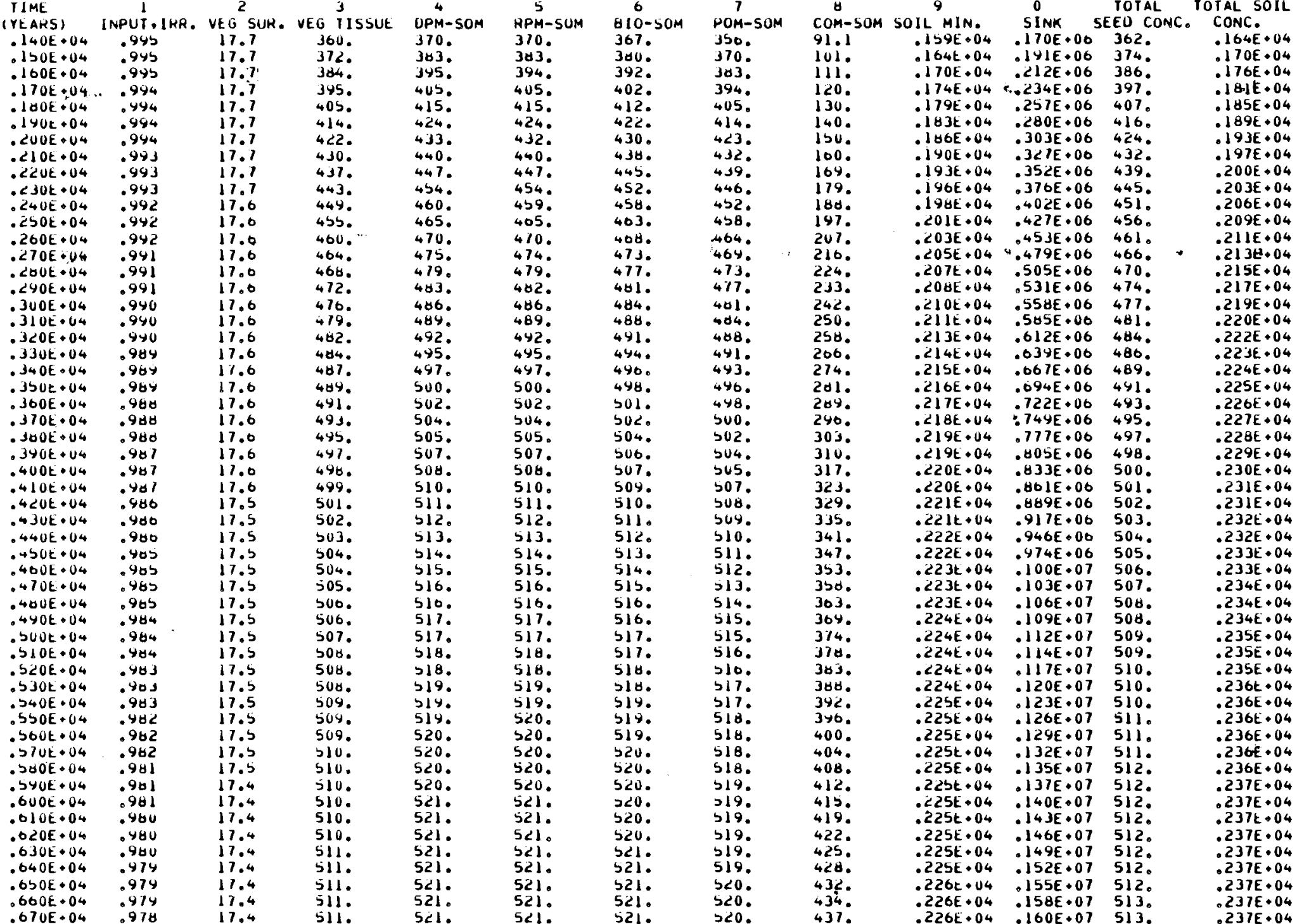


NUCLIIOE = TC-YY PHYSICAL HALF = .21JE-UOYEAHS, T-ZERO = 0 , YEARS, T-MAX = . 100E.05 YEARS,

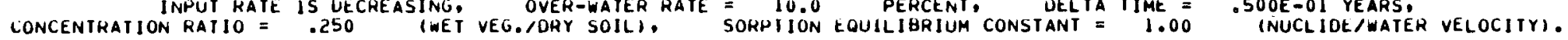
C INITIAL TOTAL UNITS

$\begin{array}{cc}\text { INITIAL TOTAL UNITS } \\ \text { OF ACIIVIIY (UOA) } \\ 1980.0 & \text { MASS (KG) } \\ 0 . & 1980.0 \\ 0 . & 1.4000 \\ 0 . & 2.8000 \\ 0 . & 17000 E-01 \\ 0 . & 1.0300 \\ 0 . & 98000 \\ 0 . & 25.200 \\ 0 . & 28.200 \\ 0 . & 1.0000\end{array}$

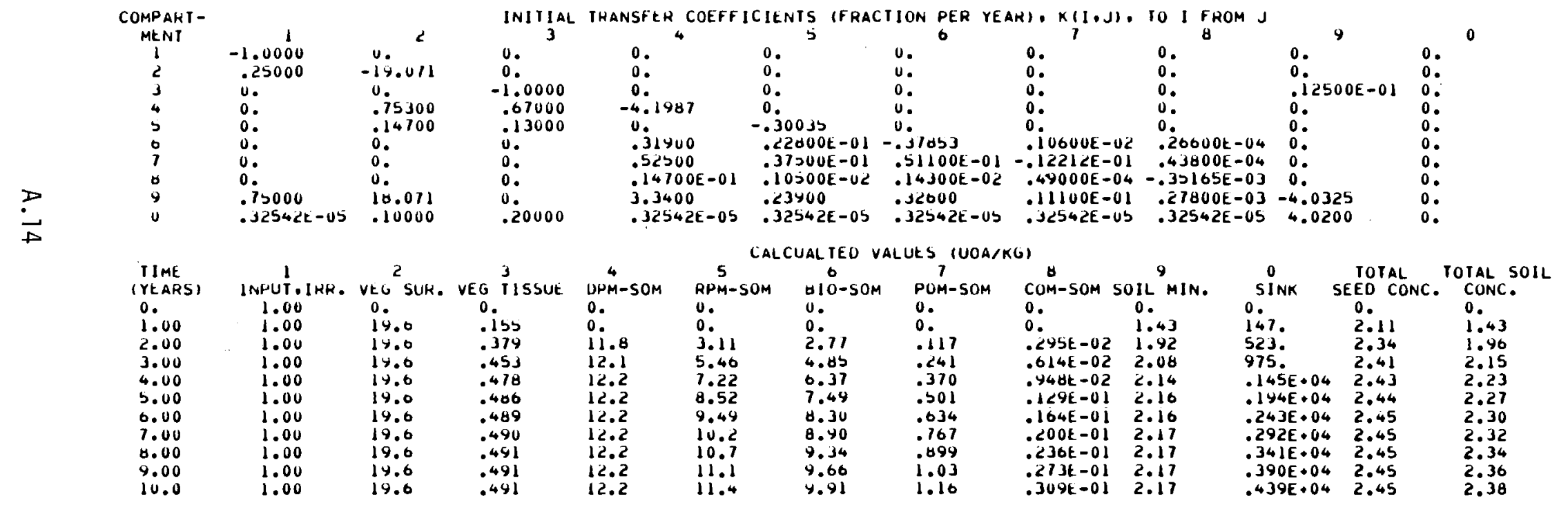




\section{DISTRIBUTION}

No. of

Copies

OFFSITE

A. A. Churm

DOE Patent Division

9800 South Cass Avenue

Argonne, IL 60439

27 DOE Technical Information Center

2 Argonne National Laboratory

Reference Library

9800 South Cass Avenue

Argonne, IL 60439

N. F. Barr

DOE Office of Health and

Environmental Research

Washington, DC 20545

Battelle Memorial Institute

Office of Nuclear Waste

Isolation

Attn: Beverly Rawles

505 King Avenue

Columbus, $\mathrm{OH} 43201$

W. G. Belter

DOE Office of Health and

Environmental Research

Washington, DC 20545

E. A. Bondietti

Oak Ridge National Laboratory P.O. Box $X$

Oak Ridge, TN 37830

2 Brookhaven National Laboratory

Reference Section

Information Division

Upton, Long Island, NY 11973
No. of

Copies

H. C. Burkholder

Office of Nuclear Waste

Isolation

Battelle Memorial Institute

505 King Avenue

Columbus, $\mathrm{OH} 43201$

W. W. Burr

DOE Office of Health and

Environmental Safety

Washington, DC 20545

20 Wayne A. Carbiener

Office of Nuclear Waste

I solation

Battelle Memorial Institute

505 King Avenue

Columbus, $\mathrm{OH} 43201$

R. C. Clusen

Assistant Secretary for

Environment

Department of Energy

Washington, DC 20545

Carl R. Cooley

DOE Office of Waste Management

Washington, DC 20545

J. C. Corey

Savannah River Laboratory

I. E. duPont

Aiken, SC 29801

R. C. Dahiman

DOE Office of Health and

Environmental Safety

Washington, DC 20545

Jared Davis

Nuclear Regulatory Commission

Washington, DC 20555 
No. of

Copies

P. J. Dostie

Department of Human Services

State of Maine

Augusta, ME 04333

P. B. Dunaway

DOE Nevada Operations Office

P. 0. Box 14100

Las Vegas, NV 89114

R. W. Englehart

Radiological Programs

NUS Corporation

4 Research Place

Rockville, MD 20850

Environmental Protection Agency

Office of Radiation Programs

Technical Assessment Division Aw559

Washington, DC 20460

C. W. Francis

Environmental Sciences Division

Oak Ridge National Laboratory

P.0. Box $X$

Oak Ridge, TN 37830

R. E. Franklin

DOE Office of Health and

Environmental Safety

Washington, DC 20545

C. T. Garten, Jr.

Environmental Sciences Division

Oak Ridge National Laboratory

P.0. Box $X$

Oak Ridge, TN 37830

Bruno Giletti

Dept. of Geological Sciences

Brown University

Providence, RI 02912

L. S. Gomez

Division 5413

Sandia Laboratories

Albuquerque, NM 87114
No. of

Copies

T. E. Hakonson

Group H-12

Los Alamos Scientific Laboratory

Los Alamos, NM 97544

John Handin, Director

Center for Tectonophysics

Texas A\&M University

College Station, TX 77840

Col in A. Heath

DOE Division of Waste

Management

Washington, DC 20545

William M. Hewitt

Office of Nuclear Waste Isolation

Battelle Memorial Institute

505 King Avenue

Columbus, $\mathrm{OH} 43201$

F. 0. Hoffman

Oak Ridge National Laboratory

P.0. Box X

Oak Ridge, TN 37830

Muzaffer Kehnemuyi

Office of Nuclear Waste

Isolation

Battelle Memorial Institute

505 King Avenue

Columbus, $\mathrm{OH} 43201$

John F. Kircher

Office of Nuclear Waste Isolation

Battelle Memorial Institute

505 King Avenue

Columbus, $\mathrm{OH} 43201$

2 Lawrence Berkeley Laboratory

Reference Library

University of California

Berkeley, CA 94720 
No. of

Copies

2 Lawrence Livermore Laboratory Reference Library

P.0. Box 808

Livermore, CA 94550

C. A. Little

Health and Safety Research

Division

Oak Ridge National Laboratory

P.0. Box X

Oak Ridge, TN 37830

2 Los Alamos Scientific Laboratory

Reference Library

P.0. Box 1663

Los Alamos, NM 87544

John Lyons

Dept. of Earth Scineces

Dartmouth College

Hanover, NH 03755

0. D. Markham

Environmental Sciences Bianch

Health Sciences Laboratory

DOE Idaho Operations office

550 Second Street

Idaho Falls, ID 83401

H. McCammon

DOE Office of Health and

Environmental Safety

Washington, DC 20545

John T. McGinnis

Office of Nuclear Waste

Isolation

Battelle Memorial Institute

505 King Avenue

Columbus, $\mathrm{OH} \quad 43201$

Sheldon Meyers

DOE Office of Nuclear Waste

Management

Washington, DC 20545
No. of

Copies

2 Barry N. Naft

NUS Corporation

4 Research Place

Rockville, MD 20805

J. 0. Neff

Department of Energy

Columbus Program Office

505 King Avenue

Columbus, $\mathrm{OH} 43201$

Y. $\mathrm{Ng}$

Lawrence Livermore Laboratory

University of California

P.0. Box 808

Livermore, CA 94550

2 Neil A. Norman

Environmental Sciences

Department

Bechtel National Inc.

P.0. Box 3965

San Francisco, CA 94105

2 Oak Ridge National Laboratory

Central Research Library

Document Reference Section

Oak Ridge, TN 37830

W. S. Osburn, Jr.

DOE Office of Health and

Environmental Safety

Washington, DC 20545

A. F. Perge

DOE Office of Nuclear Waste Management

Washington, DC 20545

George Pinder

Dept. of Civil Engineering

Princeton University

Princeton, NJ 08540 
No. of

Copies

J. E. Pinder

Savannah River Ecology

Laboratory

Drawer E

Aiken SC 29801

Gary Robbins

U.S. Nuclear Regulatory Commission

Division of Waste Management

Washington, DC 20555

2 Savannah River Laboratory

Reference Library

Aiken, SC 29801

G. Schwarz

Health and Safety Research

Division

Oak Ridge National Laboratory

P.0. Box $X$

Oak Ridge, TN 37830

Raymond Siever

Dept. of Geological Sciences

Harvard University

Cambridge, MA 02138

Howard P. Stephens

Sandia Laboratories

P.0. Box 5800

Albuquerque, NM 87115

David B. Stewart

U.S. Geological Survey

National Center 959

Reston, VA 22092

R. L. Watters

DOE Office of Health and

Environmental Safety

Washington, DC 20545

F. W. Whicker

Department of Radiology and

Radiation Biology

Colorado State University

Ft. Colling, CO 90523
No. of

Copies

G. C. White

Group $\mathrm{H}-12$

Los Alamos Scientific Laboratory

Los Alamos, NM 87544

T. F. Winsor

Rockwell International

Rocky Flats Operations

P.0. Box 464

Golden, C0 80401

\section{FOREIGN}

R. Amaris

EURATOM

Health Physics Division

29, Rue Aldringer

Luxembourg

BELGIUM

H. D. Brenk

Nuclear Research Center

Jülich,

FEDERAL REPUBLIC OF GERMANY

R. S. Bruce

Agriculture Research Council

Letcombe Laboratory

Wantage, 0X12 9JT

ENGLAND

Bundesministerium fur Forschung und Technologie

Stressemannstrasse 2

D-5300 Bonn

FEDERAL REPUBLIC OF GERMANY

Ferruccio Gera

Radiation Protection and Waste Management Division

Nuclear Energy Agency/OECD

38 boulevard Suchet

75016 Paris

FRANCE 
No. of

Copies

D. J. Gorman

Environmental/Internal

Dosimetry Section

Ontario Hydro

Central Health Physics Services

Box 160

Pickering, Ontario LIV 2R5

CANADA

S. Hartwig

Battelle-Institut e.V.

Am Römerhof 35

6000 Frankfurt (Main) 90/

FEDERAL REPUBLIC OF GERMANY

2 INIS Clearinghouse

International Atomic Energy Agency

P.0. Box 590

A-1011, Vienna

AUSTRIA

G. N. Kelly

National Radiological Protection Board

Harwe11, Didcot

Oxfordshire 0X110RRQ

ENGLAND

Library

Studsvik Energiteknik $A B$

S-611 01 Nykoping

SWEDEN

J. A. K. Reid

Storage and Disposal Branch

Atomic Energy of Canada Limited

Pinawa, Manitoba ROE ILQ

CANADA

Egbert Schapermeier

Battelle-Institute e.v.

Am Römerhof 35

D-6000 Frankfurt am Ma in 90

FEDERAL REPUBLIC OF GERMANY
No. of

Copies

M. Schmid-Albrecht

German Federal Health Office

Institute for Radiation Hygiene

D-8042 Neuherberg

FEDERAL REPUBLIC OF GERMANY

T. Vandergraff

Atomic Energy of Canada Limited Whiteshell Nuclear Research Establ ishment

Pinawa, Manitobe ROE ILQ CANADA

P. Vasudev

Nuclear Programs Division

Place Vincent Massey

4 th Floor

Ottawa, Ontario KIA IC8

CANADA

ONSITE

12 DOE Richland Operations Office

T. E. Austin

J. C. Cummings

0. J. Elgert/J. L. Roades

R. E Gerton

B. R. Goranson

H. E. Ransom

J. J. Schreiber

M. W. Shupe

F. R. Standerfer/P. G. Harris

M. W. Tiernan/D. R. Elle

M. G. White

M. J. Zamorski

1 UNC Nuclear Industries

T. E. Dabrowski

1 Hanford Engineering Development Laboratory

G. D. Carpenter 
No. of

Copies

11 Rockwell Hanford Operaions

R. A. Deju

R. D. Fox

G. S. Hunt

R. E. Isaacson

R. L. Koontz

P. G. Lorenzini

D. Paine

J. V. Panesco

R. C. Routson

D. D. Wodrich

Rockwell Document Control

79 Pacific Northwest Laboratory.

W. J. Bair

D. A. Baker

A. Brandstetter (5)

L. L. Cadwell

D. A. Cataldo

J. F. Cline

J. J. Fuquay

T. R. Garland
No. of

Copies

R. 0. Gilbert

K. E. Harding (3)

G. R. Hoenes

B. W. Howes

L. H. King

M. R. Kreiter

D. E. Olesen

A. M. Platt

R. G. Schreckhise (30)

J. K. Soldat

J. M. Thomas

W. H. Rickard

D. Silviera

W. L. Templeton

C. M. Unruh

B. E. Vaughan

E. C. Watson

R. E. Wildung

W. R. Wiley

Technical Information (5)

Publ ishing Coordination (2)

Water and Land Resources

Department Library (10) 